\title{
Fiduciary Duties and Equity-Debtholder Conflicts
}

\section{Citation}

Becker, Bo, and Per Stromberg. "Fiduciary Duties and Equity-Debtholder Conflicts." Review of Financial Studies 25, no. 6 (June 2012): 1931-1969.

\section{Published Version}

http://rfs.oxfordjournals.org/content/early/2012/03/12/rfs.hhs006.full.pdf?

keytype=ref\&ijkey=F1HMpPRXIEeWzze

\section{Permanent link}

http://nrs.harvard.edu/urn-3:HUL.InstRepos:9491449

\section{Terms of Use}

This article was downloaded from Harvard University's DASH repository, and is made available under the terms and conditions applicable to Open Access Policy Articles, as set forth at http:// nrs.harvard.edu/urn-3:HUL.InstRepos:dash.current.terms-of-use\#OAP

\section{Share Your Story}

The Harvard community has made this article openly available.

Please share how this access benefits you. Submit a story.

Accessibility 


\title{
Fiduciary Duties and Equity-Debtholder Conflicts
}

\author{
Bo Becker and Per Strömberg ${ }^{* * *}$
}

January, 2012

\begin{abstract}
We use an important legal event to examine the effect of managerial fiduciary duties on equity-debt conflicts. A 1991 legal ruling changed corporate directors' fiduciary duties in Delaware firms, limiting managers' incentives to take actions favoring equity over debt for distressed firms. After this, affected firms responded by increasing equity issues and investment and by reducing risk. The ruling was also followed by an increase in leverage, reduced reliance on covenants, and higher values. Fiduciary duties appear to affect equity-bond holder conflicts in a way that is economically important, has impact on ex ante capital structure choices, and affects welfare.
\end{abstract}

JEL: G32, G33, L2

\footnotetext{
* Becker (bbecker@hbs.edu): Harvard Business School and National Bureau of Economics research (NBER); Strömberg (per.stromberg@sifr.org): Institute of Financial Research (SIFR), Stockholm School of Economics, ECGI, and CEPR. Becker (corresponding author): Baker Library Bloomberg Center, Harvard Business School, Boston MA 02163; telephone: (617) 4965335.

** We would like to thank Lynn LoPucki for sharing data, Kathryn Chiu and Rimma Yusim for research assistance, and an anonymous referee, Bill Allen, Ken Ayotte, Douglas Baird, Carliss Baldwin, Patrick Bolton, Matthieu Bouvard, Thomas Chemmanur, John Coates, Mihir Desai, Alex Edmans, Stu Gilson, Todd Gormley, Jeremy Graveline, Rocco Huang, Marcin Kacperczyk, Mark Leary, Michael Lemmon, Ed Morrison, Jeff Netter, Raghuram Rajan, Mark Roe, David Scharfstein, Albert Sheen, Suraj Srinivasan, Guhan Subramanian, Jeremy Stein, Michael Weisbach (the editor) and seminar participants at Harvard, Rice, Tel Aviv, Columbia, Wharton, Ohio State, SIFR, the 2011 AFA meetings, the 2010 UBC Winter Conference, the Third McGill Risk Management Conference, the NYU / Penn Law and Finance Conference, Chicago, Gerzensee, Bocconi, INSEAD, University of Zürich, and IE Business School for comments and suggestions.
} 
One of the cornerstones of U.S. corporate governance is that directors and officers should firms to maximize shareholder value. It is well understood, however, that shareholder maximization does not necessarily lead to welfare maximization. Decisions that increase shareholder value may impose costs on other stakeholders, e.g. creditors, employees, or the environment, which are not internalized by shareholders. One important instance is the conflict between equity- and debt holders in financial distress. ' Shareholders of distressed firms may prefer low investment, may want to limit new equity finance, and may like high risks, since it benefits the value of equity at the expense of debt. ${ }^{\text {ii }}$ Despite these problems, the prevailing view among economists is that shareholder maximization is the secondbest solution to the corporate governance problem. ${ }^{\text {iii }}$

Fiduciary duties of directors and officers to the corporation and its shareholders constitute one mechanism ensuring that firms are run in shareholders' interest. These duties require that officers take actions that are in the interest of owners. If officers fail to do so, shareholders can sue them. This mechanism provides management with an incentive to act in shareholders' interest. Some observers have argued that the shareholders' ability to sue for breach of duty is of limited use as a governance tool (see e.g. Macey 1991 and Becht et al 2003). First, managers are subject to other governance mechanisms, such as financial incentives, termination risk, or career concerns, which arguably are more important than the threat of shareholder lawsuits. " Second, the "business judgment rule" gives managers considerable legal flexibility, making lawsuits against managers hard to win for shareholders. ${ }^{v}$ Finally, directors and officers typically take out insurance against shareholder lawsuits, which should limit the extent to which such lawsuits discipline management. ${ }^{\text {vi }}$ Despite this debate, the ability of managerial fiduciary duties to affect corporate governance has not been empirically tested.

We present a novel approach to studying the importance of fiduciary duties in the context of debt-equity conflicts, employing a 1991 legal event as a natural experiment. Historically, the position of 
U.S. courts was that for solvent firms, fiduciary duties are owed to the firm as a whole and to its owners, but not to other firm stakeholders, such as creditors. ${ }^{\text {vii }}$ If a firm becomes insolvent, fiduciary duties are owed to all interested parties (including creditors), but as long as the firm is solvent the creditors hold no such rights. This changed with a Delaware court's ruling in the 1991 Credit Lyonnais v. Pathe Communications bankruptcy case. ${ }^{\text {viii }}$ The case ruling argued that when a firm is not insolvent, but in the "zone of insolvency", duties are already owed to creditors. This ruling was immediately recognized as an important precedent. There was extensive press coverage of the case, and considerable debate and analysis about its implications, in the following months. The case was widely understood to have created a new obligation for directors of Delaware-incorporated firms. For example, in March, Forbes Magazine reported that, following "a recent decision by William Allen... when a company is in serious trouble, the director's responsibility shifts somewhat in the direction of the creditors" (Forbes, 1992).

The Credit Lyonnais v. Pathe Communications legal episode provides an opportunity to assess the importance of fiduciary duties. Starting in 1992, directors of Delaware corporations, but not of firms incorporated elsewhere, had stronger duties to creditors. If duties are important to managers, this event could change corporate behavior, limiting the willingness of directors and managers to take actions favoring equity at the expense of debt. Using a difference-in-difference methodology, we examine corporate policies and capital structure outcomes in a sample of public firms around the Credit Lyonnais ruling. The difference-in-difference methodology contrasts firms incorporated in Delaware to those incorporated elsewhere, and before 1991 to after. Since the case only created new duties for firms in the zone of insolvency, any changes in corporate behavior which were driven by Credit Lyonnais should be particularly visible for firms in financial distress, but might be absent altogether for firms that are far from financial distress. Because of this, we focus on firms that are more financially distressed, using a measure of distance-to-default similar to Vassalou and Xing (2004). 
Our tests examine some of the main debt-equity conflicts that have been proposed. First, when a firm is highly leveraged, and debt is risky, equity-holders have a disincentive to raise new capital to invest in projects that would make debt safer, even if these projects have a positive net present value. This is commonly known as the debt overhang problem (Myers 1977). If the 1991 change in fiduciary duties reduced the debt overhang problem, investment and equity issuance should increase for firms affected by the Credit Lyonnais ruling. Second, equity-holders have an incentive to increase the riskiness of the firm's existing assets, even in some cases when this would reduce the value of the firm. This conflict is commonly known as the risk-shifting problem (Jensen and Meckling 1976). If Credit Lyonnais decreased risk-shifting incentives, firm volatility would be predicted to decrease for firms affected by the ruling. A third implication of both of these theories is that the inability of equity-holders to precommit not to under-invest or shift risk should make debt more costly and less desirable ex ante, since creditors will protect themselves through higher interest and restrictive covenants. Hence, we would predict that the cost of debt should decrease and the use of debt should increase for firms affected by the ruling. Fourth, since Credit Lyonnais gave creditors more power, we predict that alternative control mechanisms available to creditors, especially contractual protection through covenants (Smith and Warner 1979), should be used less if fiduciary duties serve to mitigate this conflict.

We find evidence consistent with most of these predictions. First, Delaware firms relatively close to financial distress become more likely to issue equity in the wake of Credit Lyonnais. This increase is apparent in unconditional data as illustrated in Figure 2, which shows how the frequency of positive net equity issuance was the same across Delaware and non-Delaware firms until 1991, that the rate of issuance was higher after 1991 for both groups, and that the increase was larger in Delaware firms. We confirm this result in tests with firm controls and year and firm fixed effects. Similarly, we find that investment increased after Credit Lyonnais for Delaware firms closer to financial distress. This is true for capital expenditures as well as for R\&D and the changes are economically significant. Together, the 
increase in equity issues and investment for affected firms are consistent with a reduction in debt overhang problems after the Credit Lyonnais ruling.

Second, we find that after Credit Lyonnais, the standard deviation of Return On Assets (ROA) falls (again, only for high leverage firms), the monthly standard deviation of equity returns falls, and the implied volatility of assets falls. These findings are consistent with the change in fiduciary duties also reducing the risk-shifting problem.

Third, consistent with Credit Lyonnais reducing ex ante agency costs of debt, we find that net debt of Delaware firms increased by approximately one percent of book assets after 1991 (relative to the change for non-Delaware firms). We also find that new Delaware bond issues include fewer covenants in the wake of the Credit Lyonnais ruling. The reduction in covenants is concentrated in those bond issuers that are closer to distress. This suggests that creditors with better control of conflicts of interest through one mechanism (duties) can reduce the reliance on other mechanisms (contract provisions).

The welfare implications of these findings are not obvious, however. On the one hand, it is possible that more creditor-friendly director duties reduce agency costs of financial distress. This would improve welfare and increase firm value, in which case both equity and debt values should increase after the new ruling. On the other hand, the new fiduciary duties may simply produce a reallocation from equity to debt, generating no net reduction in the costs of financial distress. In this case, the price of debt could still increase, but the price of equity could go down, leaving the aggregate firm value unaffected or even decreasing. In this case, there are no positive aggregate welfare effects. In order to distinguish between these theories we examine the change in equity values around the time of Credit Lyonnais. We find that Delaware firms' equity value increased by 61 basis points (equal weighted) relative to non-Delaware firms on Dec, 30, 1991, the day that the case ruling was announced and by 206 
basis points over the subsequent five days. The positive equity returns suggests that the welfare effects of the Credit Lyonnais ruling were positive on average. ${ }^{\text {ix }}$ Even if the ruling reduced costs of debt ex ante, however, the ruling might be bad news for firms that were already in financial distress, since Credit Lyonnais made actions favoring equity over debt less feasible. Consistent with this, we find that the positive effects on equity value are concentrated among the firms high and moderate distance-todefault.

Our paper connects to several strands of research. First, it is generally related to the literature on stakeholder corporations and the optimal allocation of corporate control rights (see Zingales, 2000) and the discussion of whether fiduciary should be extended to other stakeholders (see e.g. Tirole, 2001). Our evidence suggests that extending fiduciary duties to include creditors for firms close to insolvency may be welfare-increasing. Second, the paper is related to the trade-off theory of capital structure and other work on the agency costs of debt. The agency costs arising from conflicts of interests among holders of equity and debt may be an important source of indirect costs of financial distress. Such costs are potentially empirically important in light of the large apparent tax advantages of debt in conjunction with modest leverage levels (e.g. Graham 2000). ${ }^{x}$ Unfortunately, these agency costs are hard to identify empirically and their importance, and even existence, is not well established. ${ }^{\mathrm{xi}}$ Our findings suggest that debt-equity conflicts do exist, are economically important, and can be affected by changes in managerial fiduciary duties. Finally, our paper is related to literature on competition between states in corporate law (see, e.g., Bebchuk, Cohen and Ferrell 2002). The Credit Lyonnais duties are a prime example of how important the Delaware courts are, and how the differences between Delaware corporate law and other jurisdictions can be of significance.

\section{Fiduciary duties and the Credit Lyonnais v. Pathe}

\section{Communications case}


Under US law, corporate directors of solvent firms are understood to owe fiduciary duties to the corporation and its stockholders. When a firm is insolvent, however, the corporation's creditors can also sue directors for breach of fiduciary duties. The question is what happens when a firm is getting close to insolvency. Prior to Credit Lyonnais, the generally held understanding of Delaware law was that officers did not owe fiduciary duty to creditors prior to insolvency. The Credit Lyonnais case changed this understanding, and created fiduciary duties sometime prior to bankruptcy and insolvency. Following this case, there was arguably a lot of uncertainty among firms and lawyers about exactly when and to what extent fiduciary duties switched in favor of creditors. This uncertainty was largely unidirectional, however, in the sense that the ruling could have more or less impact for Delaware firms, but only in ways favoring creditors. ${ }^{\text {xii }}$ Hence, we believe the Credit Lyonnais provides a good experimental setting for evaluating the impact of fiduciary duties on firm behavior.

The Credit Lyonnais case followed the leveraged buyout of MGM Corporation in November 1990, financed by several banks and Time Warner (the seller). The newly private company had trouble meeting financial obligations almost immediately, and trade creditors forced it into bankruptcy within five months. As part of the exit from bankruptcy, MGM secured a credit line from the U.S. subsidiary of Credit Lyonnais, a French bank. Pathe Communications, MGM's controlling stockholder, and Credit Lyonnais also entered into a corporate governance agreement. Subsequently, Credit Lyonnais used its contractual right under that agreement to replace MGM directors, including the CEO. Pathe's owners felt the new CEO favored creditor's interests, and sued, claiming among other things that the new CEO breached a duty of good faith owed to them.

The case (which in fact consisted of several lawsuits considered together) was ruled by Chancellor William Allen, a respected Delaware judge. In the November 1991 ruling, the court held that the CEO had been "appropriately mindful of the potential differing interests between the corporation 
and its 98\% shareholder. At least where a corporation is operating in the vicinity of insolvency, a board of directors is not merely the agent of the residue risk bearers, but owes its duty to the corporate enterprise". In footnote 55 of the ruling, the fiduciary duties of firms in financial distress were discussed: "in the vicinity of insolvency, circumstances may arise when the right (both the efficient and the fair) course to follow for the corporation may diverge from the choice that the stockholders... would make".

The Credit Lyonnais case, and especially footnote 55 , quickly became the focus of attention in the business press and among lawyers. There was immediate news wire coverage: Reuters reported a long newswire on December 30, titled "Court upholds Parretti Ouster from MGM", focusing on how the decision favored creditors over the owners. ${ }^{\text {xiii }}$ Both Dow Jones and PR Newswire also covered the ruling on December 30. The Wall Street Journal covered the story extensively the following day, emphasizing that the ruling confirmed the bank's extensive governance role (but did not explicitly mentioning the fiduciary duties of the board or footnote 55). Apart from the Wall Street Journal, there were at least twenty-three newspaper stories about the case the following day (including The Baltimore Sun, Chicago Sun-Times, Houston Chronicle, Financial Post, The Globe and Mail, The Las Vegas Review-Journal, The San Francisco Chronicle, the New York Times, Financial Times, St Louis Post-Dispatch, and the Washington Post). Figure 1 summarizes the media attention around the case.

Very quickly, news stories and analysis by legal scholars emphasized that the change in governance took the form of new fiduciary duties for directors of Delaware corporations. The case was perceived by many to have outlined a fiduciary duty of corporate officer to creditors, for firms in what has usually been called the "zone of insolvency". On February, 1, 1992, The Financial Times' Business Law Brief discussed the change of fiduciary duties and reported that "boards of directors of Delaware companies who might be 'in the vicinity of insolvency' are pondering the implications of the Chancellor's 
pronouncement" (Financial Times Business Law Brief 1992). In March of 1992, Forbes Magazine explained the implications in plain English: "when a company is in serious trouble, the director's responsibility shifts somewhat in the direction of the creditors". The magazine also emphasized both the legal attention (the case had "corporate lawyers buzzing ") and the broad implications for directors: "All this is of intense interest at a time when many junk-bond-financed companies are frequently on the edge of insolvency. The job of their directors may be complicated by Chancellor Allen's ruling" (Forbes 1992).

The case is extensively cited by other cases, legal scholars, and practicing lawyers. It is discussed in textbooks and law firm memos and taught at law schools. ${ }^{\text {iv }}$ Referring to the 1993 meeting of the American Bar Association, a participant commented: "Credit Lyonnais generated considerable comment and controversy over the additional obligations imposed on -- and thus the potential liability of -- boards of directors". ${ }^{\mathrm{xv}}$ Lawsuits citing Credit Lyonnais appeared in the next several years following ruling. ${ }^{\text {xvi }}$ The fiduciary duties implied by Credit Lyonnais were invoked as matter of fact in educational materials for practicing bankruptcy lawyers: “...directors of corporations merely in the 'vicinity' of insolvency owe duties to creditors" (Hughes and McGee 1995).

Delaware courts handled many bankruptcies and other corporate legal matters during the sample period we consider, but no other case relating to bankruptcy seems to have been as important or have received anything like the wide attention devoted to Credit Lyonnais. Approximately fifteen Delaware cases were mentioned in the Wall Street Journal during 1991-1992. While the Wall Street Journal only provides a crude proxy for legal importance, it likely does reflect public attention fairly well. The cases mentioned in the WSJ related to product liability, class action law suits, financial reporting, merger and acquisitions and anti-trust. None of the cases discuss the ruling in any detail, and most are only brief notes. Only one of the cases concerned fiduciary duties, in relation to a merger (some 
shareholders thought the board made the wrong decision about a tender offer). Unlike Credit Lyonnais, none of these cases appear to have set important precedents.

Two recent Delaware cases, Production Resources (2004) and Gheewalla (2007), represent a partial reversal of Credit Lyonnais. Specifically, these rulings took away the "sword" (i.e. the ability of creditors to sue directors for breach of fiduciary duty) but left the "shield" intact (i.e. the protection from lawsuits by shareholders). From the Production Resources ruling: "In other words, Credit Lyonnais provided a shield to directors from stockholders who claimed that the directors had a duty to undertake extreme risk so long as the company did not technically breach any legal obligations." So after these two cases, directors have a defense against lawsuits by owners which did not exist before Credit Lyonnais, but no additional exposure to lawsuits from creditors." The future relevance of duties to creditors, at least in the specific format Credit Lyonnais was interpreted as defining, is therefore somewhat reduced. We discuss the subsequent cases in Section III.I below.

A key part of our identification is that the Credit Lyonnais ruling set a precedent for firms incorporated in Delaware, but had no prejudicial power for other firms. Because about half of U.S. public corporations are incorporated there, the case provides a useful division of public firms into treated and untreated groups. This division relies on a firm distinction between Delaware and non-Delaware corporate law. However, other jurisdictions may incorporate ideas and learn from Delaware (see Linos 2006). Our empirical strategy relies on the comparison of firms incorporated in Delaware relative to those outside Delaware, so such "leakage" might reduce the power of our tests. We believe this problem is limited for three reasons. First, fiduciary duties can be the subject of legislation, and thereby outside of the scope of precedents. ${ }^{\text {xii }}$ We have implemented our tests excluding states without constituency statutes, i.e. where fiduciary duties are legislated (but not excluding Delaware), with similar results. ${ }^{\text {xviii }}$ Second, we restrict our tests to three years before and after the Credit Lyonnais case. 
Thus, even if there is leakage of legal rules from Delaware, but it is not very fast, it should not affect our results. Finally, if there were some leakage even during the short window we study, that will tend to obscure the impact of Credit Lyonnais. Thus, if we find significant changes after the case, as we do, this concern suggests that we may underestimate the magnitudes slightly.

\section{Data}

We collect firm level information on accounting data and state of incorporation from Compustat, covering the 1986-1997 period. Our main tests only use data for three years before (19891991) and three years after the Credit Lyonnais ruling (1992-1994), but we collect data from 1986 to 1997 for wider windows used in robustness test and to be able to calculate changes in variables. We drop utilities and financial firms. We use Compustat's incorporation code to identify the state of incorporation. Of the 6,608 firms in 1991 , we identify $44.4 \%$ as incorporated in Delaware. The Compustat incorporation data is backfilled, i.e., at any point in time, Compustat reports the current state of incorporation. This reduces concerns about endogeneity, but may introduce measurement error. For a subsample of 485 firms we verified the state of incorporation during our sample, and there were 37 differences, i.e. less than $8 \%$ of firms appeared misclassified. Moodie (2004) reports 327 reincorporations to Delaware and 34 from Delaware by New York Stock Exchange (NYSE) listed firms during the 1960-2002 period. The RiskMetrics database (covering S\&P1500 and a few other large firms every two or three years from 1990) reports 286 incorporation changes over 1990-2006, i.e. an annual frequency of around $1.0 \%$. The only period with a significant difference in the rate of reincorporations is 1999 and 2000, when the rate is $1.5 \%$ per year. Of the 103 firms in this sample that reincorporated between 1990 and 1998, 68 switched to or from Delaware. Excluding these 68 firms (or a subset of them that switched in the two years after the ruling) from our regressions has no noticeable effect on any of our estimates. 
Firm control variables are defined from Compustat and CRSP variables as follows. ROA is Ebitda divided by total assets (At). ROS is earnings before interest, tax, depreciation and amortization (Ebitda) divided by sales. The log of market value is the natural logarithm of the number of shares outstanding times the end of year share price. Leverage is assets minus common equity (book value) and minus tax liabilities, divided by assets. Market leverage is assets minus common equity (book value) and minus tax liabilities, divided by assets minus common equity (book value) and minus tax liabilities plus market value of equity. We define $Q$ as assets minus common equity (book value) plus the market value of equity minus tax liabilities, divided by assets minus 0.1 times common equity (book value) and plus 0.1 times the market value of equity. ${ }^{\text {xix }}$ Finally, two year stock return is the two-year log change in stock price. We eliminate observations where ROS is outside $[-1,1]$, where ROA is outside $[-0.5,0.5]$, where Depreciation over Assets is outside $[0,0.3]$, and where Leverage is outside $[0,1] .^{\mathrm{xx}}$

Dependent variables using Compustat data are Capex over assets (Capx divided by At), Capex and R\&D over assets (Capx plus Xrd, divided by At), and Capex and R\&D over sales (Capx plus Xrd, divided by Sale). For regressions with these variables, we exclude observations where the dependent variable is outside $[0,0.5],[0,1.3]$ and $[0,3]$, respectively. ${ }^{\text {xxi }}$ Net debt is defined as Long term debt minus cash over assets (Dlc plus Dltt minus Ch, divided by At). In regressions with this dependent variable, observations are excluded where net debt is outside the $[-0.7,1.3]$ range. We also use an indicator variable taking the value one when a firm's investment is above the median investment ratio in its industry-year. Equity issues are defined as the change in book equity minus changes in retained earnings (and adjusted for deferred taxes as in e.g. Baker, Stein and Wurgler 2003), normalized by lagged assets. Values outside the $[-0.5,1]$ range are dropped, following the winsorizing in Baker, Stein and Wurgler (low asset firms sometimes produce very large negative or positive ratios, so some winsorizing is necessary, but using wider or narrower cutoffs has little effect on the variable). We also form an indicator variable for observations with positive values for equity issues. 
Quarterly Compustat data is used to calculate the standard deviation of ROA (EBITDA over lagged assets) changes. The variable is annualized. Equity volatility is calculated as the annualized monthly standard deviation of the stock return, taken from CRSP, for the preceding calendar year. CRSP price data is also used to calculate implied asset volatility using the Merton (1974) model following the procedure of Vassalou and Xing (2004). This is calculated annually using daily price data. For volatility tests, we exclude observations where the dependent variable is very large (the volatility measure is outside $[0,1])$.

We also collect data on bond features for newly issued bonds from CapitallQ. The ultimate source is prospectuses filed with the SEC. The data covers bonds issued since 1986. For 1986 to 1999 , there maturity and covenant data is available for 17,472 corporate bond issues, 6,935 of which have no covenants. We use a narrow window of two years on either side of Credit Lyonnais, i.e. 1990-1993. For this period, there are 4,173 bonds, for which the average number of covenants is 4.66 , and the median is 4 . For bonds with covenants, the mean is 5.57 and the median 5 . We calculate maturity as the number of years remaining at issue, rounding up to nearest integer. We categorize bonds by their seniority type (Junior Subordinate, Senior Secured, Senior Subordinate, Senior Unsecured, Subordinate or Not Ranked) and coupon type (fixed, step-up, variable or zero). For a small subset of firms, we match bond issues to distance-to-default data for the issuers (from our main firm sample), based on tickers. This matching is very incomplete and reduces the sample size from 4,173 to 587 bonds. Table 7, which reports regressions where these variables are used, reports the dependent variable's mean and standard deviation for each column.

In our analysis we want to distinguish firms depending on how close they are to insolvency, since many of the predictions primarily apply for firms "in the vicinity of financial distress." To achieve this, we divide firms into groups depending on their "distance to default" according to Merton (1974). 
Intuitively, the distance to default measure does not only take in to account the amount of leverage a firm has, measured as debt relative to market value of assets, but also its asset volatility. We define as low distance to default any firm-year for which the 1989 log of the ratio of assets to debt is less than 4 times the standard deviation of assets, estimated following Merton (1974) and again following the procedure of Vassalou and Xing (2004). The cut-off of 4 closely corresponds to the median distance to default in our sample, so that the sample is cut in approximately half. In robustness tests, we also use alternative insolvency definitions, based on book leverage, Altman's Z score (Altman 1984), and dividend payer status.

For our event study, we use daily factor returns from Kenneth French's web site, together with CRSP daily returns, to estimate CAPM and Fama-French 3-factor models for January to November 1991. We only used returns calculated from consecutive transaction prices (not bid-ask spreads). The loadings (beta estimates) were used to calculate one and five day residuals for the period following the announcement of the ruling in the Credit Lyonnais case (Dec, 30,1991). Average stock returns, as well as average CAPM and FF residuals, equally- and value-weighted, were calculated for firms incorporated in Delaware and firms incorporated in other states, respectively.

\section{Results}

In this section, we evaluate the effect of the Credit Lyonnais court ruling on firms in Delaware. We employ a difference-in-difference method (see e.g. Bertrand, Duflo, and Mullainathan, 2004), using the fact that firms in Delaware were subject to a different legal environment after November 1991, but that firms outside Delaware were not. We examine a range of corporate outcomes, and use regressions with firm and year combinations defining the unit of observations. This permits controlling extensively for firm level variables. We use return on assets, return on sales, the log of assets (book value), the log of sales, the log of equity market value, depreciation over assets, book leverage (defined as assets minus 
equity minus deferred taxes, over assets), and market leverage (defined as assets minus book equity minus deferred taxes, over assets minus book equity plus market equity), two year lagged stock return, and Tobin's q (capped at 10). Depending on the particular dependent variable, we sometimes exclude control variables when this would otherwise lead to mechanical or co-linear relationships with our dependent variables. The exact set of control variables are outlined in each table.

Summary statistics for these variables for 1989-1994 are shown in Table 1, for the whole sample as well as separately for Delaware and non-Delaware firms for the pre event and post-even periods (1989-1991 and 1992-1994, respectively). Because we compare changes for Delaware and nonDelaware firms, it is interesting to see whether they are very different before the Credit Lyonnais ruling. Table 1 shows that the two subsamples are similar along most dimensions, such as profitability, payout policy, investment, net leverage and volatility, although there are some differences, notably that Delaware firms are larger on average, consistent with Bebchuk and Cohen (2003). ${ }^{x \times i i}$ By controlling for these variables throughout we make sure these differences should not drive our results. In addition, we include firm fixed effects in regressions in order to control for unmeasured heterogeneity between firms, thus reducing the potential for omitted variables problems. Because of the firm fixed effects, firms that only appear before or after the 1991 cut-off do not help identify the Credit Lyonnais coefficient in our regressions (although they do help identify other coefficients). Therefore, compositional changes in the Delaware and non-Delaware firm populations will not be econometrically important for our identification.

Baseline results cover the three years prior to the Credit Lyonnais ruling and the three years after. In robustness we also report wider windows (section $\mathrm{H}$ ). xxiii $^{\text {. }}$ 
We use heteroskedasticity-robust standard errors throughout, clustered by the interaction of year and state of incorporation. Clustering by firm gives much smaller standard errors, and doubleclustering by state*year and firm makes virtually no difference to any of the reported results.

\section{A. Predictions based on ex-post agency conflict and predictions based on ex- ante contracting responses}

Several of the theoretical predictions of models of equity-debt conflicts concern firm outcomes when equity holders take actions that may not be in the interest of debt holders. Findings of such effects are the most direct signs of agency costs in our data. First, when a firm is highly leveraged, and debt is risky, equity-holders have a disincentive to raise new capital to invest in projects that would make debt safer, even if these projects have a positive net present value. The reason is that part of the value of the investment would go to creditors by making debt less risky and expected debt recovery higher, reducing the benefits for equity value. Either it will be impossible to raise equity in this case, or an equity-issue would have to be sufficiently dilutive (i.e. the new equityholders will have to receive a sufficiently high fraction of the total equity) so that the new equityholders will break-even on their capital infusion. ${ }^{\text {xiv }}$ Either way, managers who maximize the value of current equityholders will be reluctant to raise new capital, thus reducing investment. This conflict was first emphasized by Myers (1977) and is commonly known as the debt overhang problem. If the change in fiduciary duties reduces the debt overhang problem, we would predict that investment and equity issuance should increase for distressed firms affected by the Credit Lyonnais ruling. Second, equity-holders have an incentive to increase the riskiness of the existing assets, even in cases when this reduces the net present value of the firm. This is because the benefits of higher risk primarily go to equity-holders thanks to their limited liability, while the costs are primarily born by creditors. This conflict is commonly known as the risk-shifting problem (Jensen and 
Meckling 1976). If Credit Lyonnais decreased risk-shifting incentives, we would expect firm volatility to decrease for distressed firms affected by the ruling.

These "ex-post" predictions about debt-equity conflicts primarily apply to firms that are closer to insolvency. For debt overhang, the key determinant is to what extent debt is risky (i.e. might not be repaid in full). For risk shifting theories, firms with higher leverage are likely to have opportunities to change value through volatility increases. In both cases, the relation between leverage and distress is likely increasing but not necessarily monotone. To measure distress and leverage, we primarily rely on distance-to-default from the Merton (1974) model, and split the sample depending on whether their distance to default value in 1989 is higher or lower than 4 (which is close to the 1989 sample median). ${ }^{\mathrm{xv}}$ We also report results using alternative definitions of distress, based on book leverage, z-scores, and payout status (section $\mathrm{H}$ ), as well as results splitting the sample in to quartiles of distance to default measure rather than the median and for the full set of firms. The ex-post predictions are examined in sections $B$ to $D$ below.

Theories of debt-equity holder conflicts also predict that capital market contracting will attempt to minimize, control, or manage conflicts. Predictions about such "ex-ante" responses to "ex-post" conflicts include changes in the amount and price of debt, and the use of covenants in new debt contracts. These methods may be costly, but are presumably better than allowing ex-post conflicts free reign. To the extent that the Credit Lyonnais ruling reduced ex-post conflicts, we expect to see less use of contractual means of dealing with conflict (covenants) as well as capital structure means of dealing with conflict (keeping leverage low to reduce risk of distress).

Compared to the ex-post predictions, ex-ante predictions are likely to apply to a broader set of firms (since currently health firms may face some chance of becoming distressed). The ex-ante predictions are examined in sections $\mathrm{E}$ to $\mathrm{G}$ below. 
Finally, note that all of these predictions rely on an assumption that equityholders are unable to pre-commit ex ante not to underinvest or risk-shift ex post. More generally, one prerequisite for the Credit Lyonnais ruling to matter is that equity-holders and debt-holders are not able to contract ex ante for a shift in fiduciary duties ex post once the firm is in financial distress. In practice we do not observe attempts to write debt contracts that switch fiduciary duties towards creditors in the zone of insolvency. There could be two explanations for this. The first one is that contractual incompleteness makes such private contracts impossible or impractical, along the lines of Zingales (1998). The second explanation is that contracting parties do not see any need for such clauses, either because fiduciary duties do not matter or because duties are already optimally asssigned in existing law. If this second explanation is correct, we would not find any effect of the Credit Lyonnais ruling on corporate behavior or value. In this sense, our paper provides a test of the extent of contractual incompleteness with respect to equity-debt conflicts.

\section{B. Investment}

We first consider the ex-post predictions from the debt overhang model, which suggests that larger debt-equity holder conflicts lead to underinvestment for firms close to financial distress. If the Credit Lyonnais ruling reduces such conflicts, investment should increase for affected firms. We use three measures of investment: Capex over assets, Capex and R\&D over assets, and Capex and R\&D over sales. We control for firm variables, firm and time fixed effects, a Delaware indicator (which is absorbed by firm fixed effects), and the interaction between the Delaware dummy and a dummy for observations after 1991 ("Delaware * After 1991"), which identifies the marginal effect of being subject to expanded fiduciary duties following Credit Lyonnais. ${ }^{\text {xxvi }}$ The regressions are presented in Table 2.

In the first two columns, we regress a measure of investment on the Credit Lyonnais dummy (i.e. the interaction of a firm being incorporated in Delaware and the year being 1992 or later) and controls. 
The regressions differ in the samples they cover: whether distance to default in 1989 was below or above the median (we use 1989 to keep the firm composition stable). The overall fit of the regressions are good, mostly reflecting the high explanatory power of firm fixed effects. For the subsample closer to distress (i.e. a low distance to default), the coefficient estimate for the Credit Lyonnais (CL) indicator (Delaware firms after 1991) is positive and statistically significant at the $1 \%$ level. In other words, after 1991, investment is higher for firms incorporated in Delaware, compared to firms incorporated elsewhere, controlling for firm averages and firm level controls. The point estimate of the effect of Credit Lyonnais is an increase in capital expenditures by 48 basis points of assets. This is a fairly large effect: the mean of capital expenditures is 6.4 percent of assets per year (standard deviation $7.1 \%$ ), so this corresponds to about seven percent of average investment (and seven percent of a standard deviation). For the subsample of firms farther from distress (i.e. a high distance to default), the coefficient is lower, 31 basis points, and marginally statistically significant. Hence, consistent with a debt overhang explanation, the positive effect of the Credit Lyonnais ruling is increasing in the likelihood that a firm is distressed.

Capital expenditures are not the only form of investment, and in columns three and four, we also include R\&D expenditures in the dependent variable. This may be a more appropriate measure of investment given the underlying theory (i.e. Myers 1977 concerns all forms of investment including in intangibles), but this reduces the sample size (due to data availability for R\&D expenditures in Compustat). The implied magnitude corresponds to about a six percent increase of mean investment for the subsample of firms closer to default (column 3), and comparable to the capex magnitude. The effect is smaller and insignificant for the subsample of firms farther from default (column 4). In columns five and six, we normalize capital expenditures by sales. Again, the coefficient for the Credit Lyonnais indicator is positive and significant and the largest coefficient estimate is for firms with lower distance to default. Overall, the results for firm investment are consistent with the joint hypothesis that debt 
overhang reduces investment in distressed firms and that Credit Lyonnais reduced the extent of debt overhang by making managers more responsive to creditor's interests.

\section{Equity issues and payout}

Another ex-post implication of the debt overhang model is that when a firm is distressed, it may be in the interest of current equity-holders to increase payout and limit new equity finance, even if this forces the firm to forego valuable investment opportunities. The reason is that for firms facing debt overhang, dividends and repurchases benefit equity at the expense of debt, while equity infusions are dilutive to old shareholders since the new equity investors have to be compensated for the valuetransfer to debtholders. To the extent that Credit Lyonnais reduced conflicts of interest we would expect equity issues to increase and payout to decrease after the ruling. One caveat is that corporate payout is often subject to limitation by covenants, which may limit the effect of any changes in managerial preferences. I.e., if covenants were effective in preventing distressed firms to pay dividends before Credit Lyonnais, we may not observe any decrease in payout after the ruling. ${ }^{\text {xxvii }}$ We examine the incidence of covenants for new bonds issues in Section $\mathrm{F}$ below.

In the first two columns of Table 3 we examine net equity issues normalized by total assets. For the subsample of firms relatively closer to financial distress (low distance to default), we find a positive coefficient on the Credit Lyonnais dummy. The estimate is 89 basis points, i.e. suggesting that these firms on average issue 0.89 percent of assets (net) more than firms not subject to Credit Lyonnais. This is about fifteen percent of the sample average for the dependent variable. The coefficient is significant at the $5 \%$ level. Like the investment results, this is consistent with a reduction in debt overhang. In contrast, the coefficient for the subsample of firms farther from financial distress is small and statistically insignificant. 
Most firms have net equity issuance close to zero. To examine if Credit Lyonnais changed the likelihood of large increases in the number of shares outstanding, such as might be expected from rights offerings, seasoned equity offerings, and private equity sales, we also consider an indicator variable for having net issuance above $10 \%$ of assets. ${ }^{\text {xxviii }}$ This variable has a mean of 0.154 , i.e. $15.4 \%$ of our firmyears involve a large equity issue. Regressions are reported in columns four through six of table 3 . The coefficient for low distance to default is 0.0179 , implying a relative increase in the likelihood of large net equity issuance in a given year by $1.8 \%$ for firms affected by Credit Lyonnais, significant at the $10 \%$-level. For the subsample with high distance to default, the coefficient is small and insignificantly different from zero. Thus, some of the findings for increased equity issues result from firm-years with very substantial net equity issues.

Regressions for changes in payout policy are reported in Table 4. There is no economically significant effect for dividends (columns one through two) or repurchases (columns three through four), either for more subsamples or for the full sample. This implies that, apart from what's explained by firm controls and overall time series patterns capture by fixed effects, Delaware firms did not experience a change in payout policy compared to non-Delaware firms in the wake of Credit Lyonnais..$^{\text {xix }}$

Hence, while the results for payout is weak (possibly explained by covenants) the results for equity issues provide evidence consistent with debt-equity conflicts. The higher equity issues after 1991 in Delaware for firms closer to distress are in line with the predictions of the debt overhang hypothesis. As with investment, the test is of the joint hypothesis that debt overhang restricts equity-financed investment, and that the Credit Lyonnais ruling reduced the importance of debt overhang.

\section{Risk and volatility}

We now turn to the risk-shifting theory, which predicts that equity holders in firms with risky debt can benefit at the expense of debt-holders by increasing firm risk. This theory predicts that risk- 
shifting should decrease after the Credit Lyonnais ruling. We therefore test if there is a reduction in risk of Delaware firms after 1991, and if any such pattern is driven by relatively highly levered firms. This is a challenging test to implement, because operational risk is not easily measured. We use three proxies, each subject to some limitations. First, we use the trailing standard deviation of eight quarterly changes in ROA. This requires having at least two years of quarterly accounting data, which restricts the sample, yet provides a noisy estimate of risk. The advantage of this measure is that we avoid using financial prices, which may be affected by other factors than operating policy, and avoids errors-in-variables problems with respect to distance-to-default. The second measure is monthly equity price volatility over the last year. Because it relies on one year of history instead of two, it may be better at picking up time series changes. However, equity volatility is affected by corporate leverage as well as various market factors. To mitigate the first of these problems, we also use implied asset volatility from the Merton (1973) model as our third measure of risk. We do not attempt to split the sample into low versus high distance to default for these last two measures, since this would introduce a potentially serious errorsin-variables problem due to the fact that asset volatility is also used in the distance to default calculation.

In particular contexts, risk-shifting may involve increasing or decreasing investment (i.e. making a risky investment using firm cash, or forgoing a safe investment). Risk-shifting may also involve no change in the level of investment (i.e. replacing a safe investment with a risky one). Since there is a priori prediction about investment, we prefer to examine risk itself, which is where an unambiguous prediction exists.

Regression tests of changes in risk around 1991 are presented in table 5. In columns one and two, the dependent variable is the volatility of ROA. In order to avoid overlapping observations for the dependent variable we only use firm-year observations for 1991 and 1994 in these regressions. 
The estimated coefficient for the Credit Lyonnais indicator is negative and significantly different from zero at the $1 \%$ level using the sample of low distance to default firms. The magnitude is 76 basis points, corresponding to a ninth of the sample mean of the dependent variable. The overall fit of the regression is good, mostly reflecting the high explanatory power of firm fixed effects. ${ }^{\mathrm{xxx}}$ In contrast, for the high distance-to-default subsample in column two, the $\mathrm{CL}$ indicator is actually positive and significant at the $5 \%$ level. Although we do not have a good explanation for why volatility actually increased for firms farther from distress, the decrease in ROA volatility after the ruling for firms closer to distress is consistent with a reduction in risk-shifting incentives. In column four, we combine the full sample, showing an average effect of zero for Credit Lyonnais. In columns five and six, the dependent variables are asset volatility and equity volatility, respectively, based on past stock return data (asset volatility is inferred from a Merton model. As mentioned, we do not split the sample due to the possibly mechanical relationship between volatility and distance to default. For the full sample, the coefficient of the Credit Lyonnais indicator is negative and significant for both of these volatility measures. The coefficient estimate for asset volatility is 71 basis points, corresponding to as much as $24 \%$ of the mean value.

For two of the three measures of risk, the results in Table 4 suggest a drop in risk after Credit Lyonnais. For the third measure, there is a drop for firms that appear close to distress. These results are consistent with a deliberate reduction in volatility by corporations in Delaware after the ruling. As with the earlier findings, results for operating volatility are driven primarily by firms that are relatively closer to financial distress. We acknowledge that the evidence is somewhat indirect, in the sense that we do not know which managerial choices actually drive risk, and what management or board decisions led to a change of risk after the ruling.

\section{E. Ex ante capital structure impact}


The results on investment, equity issues, and risk suggest that agency problems between equity and debt were reduced for distressed firms after the Credit Lyonnais ruling. We now examine if there were changes in financial contracting as a response to these reductions in agency conflicts. These are what we refer to as "ex-ante" predictions.

We first test whether leverage increased (since the ex-post agency costs incurred with high debt are lower) and the costs of borrowing fell (since debt holders do not need the same compensation for future opportunistic behavior of equity holders). ${ }^{x \times x}$ In Table 6, we present regressions of various measures of leverage and interest cost on firm controls, firm and time fixed effects, and the Credit Lyonnais indicator. The controls exclude contemporaneous book and market leverage, but we do one lag of the dependent variable in each regression in order to control for leverage dynamics (i.e. to avoid leverage reversion to some target falsely appearing as an increase for distressed firms).

We present leverage tests for the full firm sample of firms, because there is no clear prediction about differences across firms (the reduction in distress costs might be more important for firms with low prior leverage or for firms with high prior leverage, we do not know a priori).

In column one, we find that the coefficient on the Credit Lyonnais indicator for net book leverage is positive and significant at the $1 \%$ level. The coefficient estimate is 66 basis points, corresponding to approximately four percent of mean net leverage. For market leverage in column two, the increase is smaller, 36 basis points or approximately a one percent increase, but statistically significant. These results suggest that leverage did indeed increase in the wake of the Credit Lyonnais ruling, albeit by a relatively small amount. The modest economic magnitude of these estimates may not be too surprising given the fact that deliberate actions drive only modest year-to-year changes in leverage (e.g., firms' market leverage is largely driven by equity price changes Welch (2004)). The results are consistent with a reduction in financial distress costs, in line with the evidence on debt 
overhang and risk shifting above. Apart from an increase in leverage, we would also expect a decrease in the cost of debt for firms affected by Credit Lyonnais. As seen from column three, however, we do not find evidence of any change in interest cost. One potential explanation for this is that our measure of cost of debt, interest expense divided by debt, is too rough. Ideally we would like to use spreads in new debt issues before and after the Credit Lyonnais ruling, but we do not have data on this for the period we are studying.

\section{F. Non-price features of new debt issues}

We next examine a further "ex-ante" prediction for financial contracting in the wake of Credit Lyonnais. A reduction in ex-post agency costs should also reduce the need for creditors to protect themselves through covenants. We therefore examine covenant use in debt contracts obtained by around the Credit Lyonnais ruling. First, we test of the incidence and number of covenants for new bond issues changes after the ruling. Many, but not all, debt contracts include a multitude of covenants aiming to protect creditors against activities that might hurt creditors or adverse selection among borrowers (Smith and Warner, 1979). Covenants may also serve to increase the incentives of creditors to monitor borrowers (Rajan and Winton 1995). Covenants also reduce managerial flexibility (Berlin and Mester, 1993), so these benefits come at a cost. To the extent that Credit Lyonnais reduce creditors' concerns about managerial opportunism for the benefit of shareholders, the need for covenants should fall around the ruling.

We examine the predictions about loser debt characteristics around Credit Lyonnais by applying the same difference-in-differences methodology used for other variables in a sample of bond issues. In other words, we compare the change in covenants for bonds issued by Delaware-incorporated firms around the 1991-1992 event with the contemporaneous change in covenants for bonds issued by nonDelaware firms. We use two years on each side, but results are similar with three year and four year 
windows (not reported). Regressions are presented in Table 7. The dependent variable is either a dummy for bonds having a covenant (column 1) or the log of the number of covenants (columns 2-4). All regressions contain issuer and year fixed effects as well as non-parametric controls for the type of coupon and level of seniority.

As predicted, Credit Lyonnais is followed by less use of covenants and longer maturities. In column one, the estimated coefficient on the Delaware*Post 1991 dummy is -0.108 , significantly different from zero at the $5 \%$ level. This implies that the propensity to use covenants falls by $11 \%$ in the wake of Credit Lyonnais (the mean of the dependent variable is $78 \%$ ). In column two, we incorporate information on the number of covenants. The coefficient estimate for the Credit Lyonnais interaction is negative, -0.154 and significant at the $10 \%$ level. This implies a drop in the average number of covenants of $14 \%$.

To the extent that fiduciary duties have changed most for firms closer to distress, the relaxation of covenant protections is predicted to be larger for these firms. ${ }^{\text {xxii }}$ For a small subsample of bond issuers we manage to link bond issuers to our main data set and can sort bond issues by issuers' distance-to-default in 1991. The sample with distance-to-default data includes 587 bond issues, i.e. constitutes approximately $15 \%$ of the full sample. We split the sample in the middle based on distance to default (i.e. so that the number of bond issues in each group is similar). Because the sample bond issuers are safer (lower distance to default) than the full firm sample, the sub-sample cutoff is higher (6.25) than that used in the firm level tests. ${ }^{\text {xxiii }}$ In columns 3 and 4 of Table 6 , we report regressions of the number of covenants on the Credit Lyonnais dummy and the full set of controls and fixed effects, for low (column 3) and high distance to default (column 4). The coefficient estimate is large and significant for low distance to default firms, but small and insignificant for high distance to default firms. In other words, the reduction in the number of covenants appears to be concentrated in firms closer to distress. 
A caveat about this result is in order: the subsample of bonds used in these tests is small, and may not be completely representative.

The full sample results and the triple difference evidence from the smaller sample, suggest that the Credit Lyonnais ruling was followed by a reduction in covenant use. The data does appear consistent with substitution away from contractual remedies of debt-equity holder conflicts as fiduciary duties changed.

\section{G. Valuation}

To assess the welfare impact of Credit Lyonnais we turn to equity values. An implication of most theories of agency costs of debt is that equity holders will pay the costs of these anticipated conflicts ex ante when the firm raises debt, through higher interest rates and more restrictive covenants, and through using less debt (thus missing out on, e.g., tax advantages). We can test this using information in stock prices. One short-coming of our approach is obviously that the short-run response of the stock market might have been wrong about the long-run impact of Credit Lyonnais. Unfortunately, later changes in the perception of the ruling's impact are harder to estimate, because over longer time periods, the stock-returns of Delaware and non-Delaware may diverge for many reasons, including idiosyncratic stock price movements.

To assess the valuation impact of Credit Lyonnais, we compare the returns of Delaware and nonDelaware firms at the time the Credit Lyonnais ruling was delivered. In general, the relative valuation of Delaware and non-Delaware firms is stable. In daily returns during 1991, the standard deviation of the equal weighted aggregate market index is 71 basis points, but the standard deviation of the Delaware non-Delaware daily return difference (also equal weighted) is only 24 basis points. Thus, we may be able to identify even fairly modest effects. According to our hypothesis Delaware firms in general should benefit from Credit Lyonnais, for example through lower interest rates, but the effect should not be 
homogenous across firms of different capital structure. For owners of firms with very high leverage, the benefits of Credit Lyonnais should be negated, or even turn negative, since equity holders may actually gain from risk shifting and other games.

The case ruling was announced on Dec, 30, 1991, was immediately reported on newswires and was covered extensively by the press the following day. ${ }^{\text {xxiv }}$ We assign December, 30 , as the announcement day, but it is plausible that the news, if relevant to market prices, would only be reflected in market prices after a few more days, or at least after news reports on the day after. As it turns out, although magnitudes change, the direction of results is not very sensitive to the number of days included in the announcement returns.

We find that Delaware firms increased in value by 60.6 basis points (relative to non-Delaware firms) on the day of the ruling, with a t-statistic of 3.1(the value-weighted differential was 41.4 basis points, t-stat 5.9). This was the second highest return differential in 1991. The positive effect was not reversed or crowded out by later returns. The five trading day window starting on December, 30 and running to January, 6, 1992, saw a 206 basis point relative increase in Delaware firm values, equal weighted, with a t-statistic of 4.9. The value-weighted five-day return was 55 basis points (t-stat 3.4). Residual returns, which control for factor loadings, may allow cleaner identification of the announcement effects. Residual from the CAPM or the Fama-French three factor model (both estimated for each stock in the first 11 months of 1991) were smaller but significantly different from zero. The various permutations of announcement returns are presented in Table 8. An alternative way of forming standard errors is to repeat the analysis for other year-ends. This will be more conservative if there are year-end Delaware-non Delaware patterns for, e.g., tax reasons. Considering the 1980/81 through 2007/08 year-ends, twenty-eight observations, the 1991/92 returns are the second highest return (comparing second to last trading day of each year) or highest (five day returns starting second to 
last trading day). The t-stats implied by the standard errors from these regressions are 2.7 (one day) and 3.0 (five days), both implying significance at the $1 \%$ level.

These effects on equity values provide further evidence that debt-equity conflict cause financial distress costs, that these costs can affect firm values in a negative way, and that ex-ante, the costs are borne by equity holders, consistent with Fama and Jensen (1983).

It may be interesting to compare the response to the Credit Lyonnais announcement across firms. Even though the average estimate is positive, distressed firms might have gained less from Credit Lyonnais (because there owners wanted to risk-shift or under-invest). Similarly, less distressed firms might have gained more (because they could increase leverage or get looser covenants). To tests this, we compare announcement returns across groups of firms based on distance to default in 1989. Obviously, this is not a perfect sort of firms by December 1991, but this ranking is consistent with regression-based tests, and it likely gives some idea of which firms should have been more or less affected by Credit Lyonnais' positive effects.

Figure 3 presents the Delaware-non Delaware return differential for December 30 by quintile of distance to default. The estimated relation between distance to default and announcement return differentials is negative. A 95\% confidence interval for the estimated regression line is plotted on the graph, showing this uncertainty about the precise slope. What is clear from the graph is that the first three quintiles (higher distress) exhibit significant positive return differentials, whereas the higher distance (low distress) quintiles do not. The general pattern is consistent with the prediction that the average benefits of Credit Lyonnais were largest for firms with positive but modest leverage, but low or insignificant for high leverage firms. In fact, it may well be the case that some firms were so distressed as to lose from Credit Lyonnais, but our sort of firms is not able to identify that (perhaps very small) set of firms. ${ }^{x x x v}$ 


\section{H. Robustness tests}

We now run several robustness tests presented in Table 9, Panels A through D. The first such test is to examine firms outside of financial distress, and to use alternative definitions of distress (reported in Panel A). As alternatives to distance-to-default, we use net book leverage, Altman's (1968) Z-score, and whether a firm pays dividends. For each measure, we sort firms based on the 1989 value of the variable, and repeat key regressions from Tables 2, 3 and 4 (Capex and R\&D, equity issues, ROA volatility) for distressed firms according to the four definitions. The different distress measures give somewhat different results. ${ }^{\text {xxvi }}$ The effect on investment is significant across distress definitions, but of larger magnitude for the sample defined using Altman's Z-score. The effect on equity issues is insignificant for Altman's Z-score, but similar across the other three distress measures. For ROA volatility, there is disagreement between measures: high leverage firms show significant reductions in volatility, and of similar magnitude to distance to default firms, but for the other two distress definitions, the coefficient estimate is insignificant. Overall, the alternative definitions agree fairly well with the distance to default measure. Leverage gives the closest agreement, z-score the least. Most likely, none of the definitions of distress captures perfectly the perception of firm management or the advice given by a firm's lawyers.

Next, we address the concern that our panel approach may overstate the statistical significance of our tests because variables are persistent and correlated over time. ${ }^{\text {xxvii }}$ In Table 9, Panel B, we therefore perform cross-sectional versions of our main tests, where the dependent variable is defined as the change in investment, equity issues, and net book leverage around the time of the Credit Lyonnais ruling. (Note that since we only used firm-year observations for 1991 and 1994 in the regressions for ROA volatility, so that this concern was not present for those tests, and we do not repeat them here.) In particular, we calculate the average value for the years 1992-1994 minus the average value for the years 
1988-1991 for our dependent variables as well as the controls. In addition, we include average log of assets and average $\mathrm{q}$ for the period $1988-1991$ as controls. Given that we use changes, we automatically difference out any (observed or unobserved) firm characteristics that are constant over time, and we cannot include firm fixed effects. This methodology is conservative, in that it reduces the number of observations and the power of our tests considerably. The cross-sectional results are qualitatively similar to the baseline panel regressions: investment and equity issues increase for the subsample of distressed firms in Delaware. Also, consistent with previous results net book leverage increases for firms affected by the ruling.

Another concern with the previous tests is that the definition of the "zone of financial distress" is somewhat vague and subjective. In the main specifications, we simply divide the sample depending on whether distance to default is below or above four. This is admittedly quite rough, and firms in the low distance to default group may be far from distress (and thus unlikely to experience a major decrease in agency conflicts in connection with the ruling) while some firms with higher distance to default may be distressed (in their own view). In particular, the binary cutoff is somewhat arbitrary. The likelihood that a firm considers itself close to distress is likely falling in our measure in a more gradual fashion. In Panel C, we repeat the difference-in-difference tests of investment, equity issuance, volatility, leverage, but by quartile of the distance-to-distress measure. We report the coefficient on the Credit Lyonnais indicator and its standard error (but no other coefficient estimates) for each quartile. The results for investment and equity issuance suggest that much of the increase after $\mathrm{CL}$ is taking place in the quartile of firms closest to financial distress. The volatility results agree with risk shifting predictions in that the two lower distance to default quartiles see drops in volatility, consistent with Table 5 (the effect is smaller but more precisely estimated for the second quartile). Also, consistent with Table 5, but puzzling, is a significant increase in volatility for some firms far from distress. All in all, the quartile 
specification agrees with the picture from the earlier tests, i.e. that Credit Lyonnais decreased agency costs when shifting fiduciary duties towards debt holders in financial distress.

The next set of robustness tests, presented in Panel $D$, aims to address concerns about business cycle variation across geographic regions and industries. For example, if the U.S. Northeast (where Delaware is) was worse hit by the 1990-91 recession, perhaps (some of) the patterns we find could be reflective of such effects. We include state times year fixed effects to deal with this concern. The key assumption is that headquarter state captures a firm's exposure to regional business cycles. Since incorporation varies within groups of firms with the same headquarter location (e.g., some of the firms located in Texas are headquartered in Delaware, some are not), this does not affect our identification strategy, although it adds a large number of fixed effects to estimate. The results in columns one to three consider investment, equity issuance and ROA volatility, respectively (for low distance to default firms). All three coefficient estimates are statistically significant in this specification. The equity issues and investment estimates are somewhat larger than the baseline, and volatility is somewhat smaller. The R-squared is increased by a couple of percentage points by in all three regressions due to the additional fixed effects. We next add fixed effects for industries interacted with year. We use twelve Fama-French industry categories. These regressions are the most conservative of our panel specifications, because they include so many additional fixed effects. Results are presented in columns 4-6 of Panel D, and are similar to the baseline findings. Estimated coefficients are slightly larger across the board. All three estimates of the Delaware*post 1991 interaction are significantly different from zero.

The results presented in Panel E of Table 9 examine the impact of changing the time window around Credit Lyonnais. The trade-off is between adding years, to get more power (observations) and to give behavioral adjustments time to manifest in the financial outcomes we study, against the higher risk 
of picking up differential trends with a longer time window. A narrower window, while limiting the amount of data we see, and setting a higher bar for how quickly behavioral changes affect observables, reduces concerns about differential trends of any kind (this is why we opt for a three year window as the baseline). Nevertheless, it may be interesting to see if the results change with a longer window. If our results represent long-term trends, and not an abrupt change, we expect to see larger coefficients with longer windows. Therefore, these window changes provide a diagnostic on our identification approach, and if results look stronger for longer windows, it may be a cause for concern. In Panel D, columns four to six, we use a four year window (i.e., 1988-1991 vs. 1992-1995), and in columns seven to nine, a five year window (i.e., 1987-1991 vs. 1992-1996). For the standard deviation of ROA, which is calculated over 12 quarters, we simply allow a gap after the Credit Lyonnais ruling, so that we compare 1989-1991 to 1993-95 (column three) and 1994-96 (column four). Results for investment and risk dependent remain statistically significant, while the coefficient estimates for equity issues become less significant. The magnitudes are lower for investment and equity issues, slightly larger for volatility. Because coefficient estimates and significance tend to fall with the length of the time window used, we conclude that differential pre-existing time trends are unlikely to affect our results.

The examination of how behavior changes over time can be pushed a little further by examining the effect year-by-year. In Figure 4, the year-by-year difference in investment between Delaware and non-Delaware firms is plotted. It is clear that there is a gradual ramp-up from 1992 to 1994, but after that, there is no apparent trend. One interpretation of this graph is that the impact of Delaware was felt with a lag, because of adjustment costs of some kind (e.g. lags between planning and implementation), but that by 1994 the full effect had been felt.

The robustness tests presented in this section suggest that the effect of Credit Lyonnais were most strongly felt for firms that appear more financially distressed, and that the results are not 
particularly sensitive to the time window chosen to examine the impact of Credit Lyonnais. This supports the interpretation of $\mathrm{CL}$ as a change in corporate decision-making toward the interests of creditors, but only for the firms where the case ruling was meant to apply, who found themselves in the zone of financial distress.

\section{Subsequent legal cases clarifying the Credit Lyonnais case}

Exactly what constituted the zone of insolvency was not perfectly clear after the Credit Lyonnais ruling. Before this issue could be settled definitively by the Delaware courts, they had backed off somewhat from the Credit Lyonnais 1991 decision. Especially the 2004 Production Resources Group v NCT and 2007 N. Am. Cath. Ed. Programming Found., Inc. v. Gheewalla cases ended up limiting the ability of creditors to sue directors for breach of fiduciary duty under Delaware corporate law. One interpretation is that Production Resources (2004) took away the "sword" (i.e. the ability of creditors to sue directors for breach of fiduciary duty) but left the "shield" intact (i.e. the protection from lawsuits by shareholders). From the case ruling: "In other words, Credit Lyonnais provided a shield to directors from stockholders who claimed that the directors had a duty to undertake extreme risk so long as the company did not technically breach any legal obligations." After the two cases, Credit Lyonnais had reduced relevance.

These cases are most likely irrelevant for our results around the Credit Lyonnais ruling, because our diff-in-diff methodology does not involve using any firm data beyond 1999, and the cases happened several years later.

However, the subsequent reduction in duties could constitute a further event study opportunity. In unreported analysis, we have failed to find any significant effects of these subsequent lawsuits. ${ }^{\text {xxviii }}$ This may not be too surprising, however, since these rulings represented a much less stark breach with the previous legal doctrine. After both of these cases, law firms still recommended its 
corporate clients that "directors should take special care in distress situations to build a record of staying informed and taking actions that best serve the entire corporate enterprise rather than any single group interested in the corporation" (see Simpson Thacher 2008).

\section{Conclusions}

The Credit Lyonnais case created fiduciary duties toward creditors in Delaware-incorporated firms within the zone of insolvency. Because this did not affect firms incorporated outside Delaware, Credit Lyonnais provides a natural experiment for examining whether and how equity-debt conflict affects firm behavior. In our tests, we find important changes in behavior after Credit Lyonnais. Relative to unaffected firms, we document an increase equity issues and investment, consistent with debt overhang. Firms reduced operational and financial risk, consistent with risk shifting and asset substitution theories. We also find evidence that leverage increases and the use of covenants falls after Credit Lyonnais. The reduction in their use is consistent with substitution among different ways of controlling conflicts between creditors and shareholders.

Credit Lyonnais appears to have had little impact on firms with low leverage or high distance to default, which is what we expect for firms which are outside the zone of insolvency, almost certainly not financially distressed, and likely far from bankruptcy. Instead, the effects are isolated to the subset of firms where financial distress is more likely.

We conclude that firms in distress sometimes have an incentive to undertake actions that hurts debt and favors equity, as predicted by some influential theories of corporate capital structure. According to theory, these behaviors lead to indirect costs of financial distress, discouraging leverage and reducing overall firm value. ${ }^{\text {xxix }}$ Indeed, we find that Credit Lyonnais was followed by slight increases in leverage, and a modest increase in average firm values around the time of announcement. Firms thus 
appear to have reaped immediate benefits of lower agency costs in the form of better access to debt at lower costs. In addition, stock prices responded positively to the ruling, especially for firms with high but not ultra-high debt, confirming the welfare impact of agency costs. ${ }^{x \mid}$ 


\section{References}

Almeida, Heitor, Murillo Campello and Michael Weisbach,2004, "The Cash Flow Sensitivity of Cash", The Journal of Finance, Vol. 59, No. 4 (Aug., 2004), pp. 1777-1804.

Almeida, Heitor, and Thomas Philippon, 2007, "The Risk-Adjusted Cost of Financial Distress," The Journal of Finance Vol. 62, pp. 2557-2586.

Altman, Edward, 1968, "Financial ratios, Discriminant Analysis and the Prediction of Corporate Bankruptcy", Journal of Finance, 23(4), 589-609.

Altman, Edward. I, 1984, "A Further Empirical Investigation of the Bankruptcy Cost Question", The Journal of Finance, Vol. 39, No. 4 (Sep), pp. 1067-1089.

Andrade, Gregor, and Steve Kaplan, 1998, 1998. “How Costly Is Financial (Not Economic) Distress? Evidence from Highly Leveraged Transactions That Became Distressed", Journal of Finance, October, 53, pp. 1443-1494.

Asquith, Paul, Robert Gertner, and David Scharfstein, 1994, “Anatomy of Financial Distress: An Examination of Junk-Bond Issuers", The Quarterly Journal of Economics, Vol. 109, No. 3 (Aug., 1994), pp. 625-658.

Ayotte, Kenneth, and Edward Morrison, 2008, "Creditor control and conflict in Chapter 11," working paper, Northwestern University School of Law.

Ayotte, Kenneth, and David Skeel, 2004, "Why do distressed companies choose Delaware? An empirical analysis of venue choice in bankruptcy," working paper, University of Pennsylvania Law School.

Baker, Malcolm, Jeremy C. Stein, Jeffrey Wurgler, 2003, "When Does the Market Matter? Stock Prices and the Investment of Equity-Dependent Firms", The Quarterly Journal of Economics, Vol. 118, No. 3 (Aug., 2003), pp. 969-1005. 
Becht, Marco, Patrick Bolton, and Ailsa Röell, 2003, "Corporate governance and control." In: G.M. Constantinides, M. Harris, and R. Stulz (eds.), Handbook of the Economics of Finance Vol. 1, 1109.Bebchuk, Lucian, and Alma Cohen, 2003, "Firms' Decisions Where to Incorporate", Journal of Law and Economics, Vol. 46, No. 2 (Oct., 2003), pp. 383-425.

Bebchuk, Lucian, Alma Cohen and Allen Ferrell , 2002, "Does the Evidence Favor State Competition in Corporate Law?“, California Law Review, Vol. 90, No. 6 (Dec., 2002), pp. 1775-1821

Berlin, Mitchell, and Loretta J. Mester, 1992, “Debt Covenants and Renegotiation”, Journal of Financial Intermediation, 2, 95-133.

Bertrand, Marianne, Esther Duflo, Sendhil Mullainathan, 2004, "How Much Should We Trust Differences-in-Differences Estimates?", Quarterly Journal of Economics, February, 119(1), pp 249275.

BNA Corporate Counsel Daily, Aug. 30, 1993

Black, Fisher, and Myron Scholes, 1973, "The pricing of options and corporate liabilities", Journal of Political Economy, 81(3), pp 637-654.

Bris, Arturo, Ivo Welch and Ning Zhu, 2006, "The Costs of Bankruptcy," Journal of Finance 61, 1253-1303. Business Law Brief Financial Times Business Information, "Directors' duties to the company", U.S. Corporate Diary, February, 1, 1992.

Chevalier, Judith A., 1995, "Capital Structure and Product-Market Competition: Empirical Evidence from the Supermarket Industry", The American Economic Review, Vol. 85, No. 3 (June), pp. 415-435

Elkamhi, Redouane, Jan Ericsson, and Christopher Parsons, 2009, "The cost of financial distress and the timing of default," working paper, McGill University.

Esty, Benjamin, 1997, "A case study of organizational form and risk shifting in the savings and loan industry", Journal of Financial Economics, 44, 57-76.

Fama, Eugene and Merton H. Miller, 1972, The theory of finance, Holt Reinhart \& Winston. 
Fama, Eugene F. and Michael C. Jensen, 1983, “Agency Problems and Residual Claims", Journal of Law and Economics, Vol. 26, No. 2, (Jun.), pp. 327-349.

Fama, Eugene, 1980, "Agency Problems and the Theory of the Firm", The Journal of Political Economy, Vol. 88, No. 2 (Apr.), pp. 288-307.Forbes Magazine, 1992, “Conflicting Interests”, 149(7), March, 30, 1992, Forbes Inc.

Franks, Julian R, and Walter Torous, 1989, "An Empirical Investigation of U.S. Firms in Reorganization", Journal of Finance, 44, 747-769.

Gennaioli, Nicola, and Andrei Shleifer, 2007, "The Evolution of Common Law", Journal of Political Economy, 115 (1), pp 43-68.

Graham, John R., 2000, "How Big Are the Tax Benefits of Debt?", The Journal of Finance, Vol. 55, No. 5 (Oct.), pp. 1901-1941.

Hughes, R.L, and M. McGee, 1995, "Fiduciary duties of directors of insolvent corporations", in A. M. Quittenden, ed., Annual current developments in bankruptcy and reorganization, New York, N.Y. : Practising Law Institute.

Jensen, Michael C., 1986, "Agency Costs of Free Cash Flow, Corporate Finance, and Takeovers", The American Economic Review, Vol. 76, No. 2, Papers and Proceedings of the Ninety-Eighth Annual Meeting of the American Economic Association (May), pp. 323-329

Jensen, Michael C., 2001, "Value maximization, stakeholder theory, and the corporate objective function," Journal of Applied Corporate Finance, Fall 2001.

Jensen, M. and W. Meckling , 1976, "Theory of the firm: Managerial behavior, agency costs, and capital structure" Journal of Financial Economics.

Johnson, Simon, Rafael La Porta, Florencio Lopez-de-Silanes and Andrei Shleifer, 2000, "Tunneling", The American Economic Review, Vol. 90, No. 2, Papers and Proceedings of the One Hundred Twelfth Annual Meeting of the American Economic Association (May), pp. 22-27. 
Kaplan, Steven, 1994, "Top executive rewards and firm performance: A comparison of Japan and the United States", Journal of Political Economy, Vol. 102, No. 3 (June), pp. 510-546.

Korteweg, Arthur, 2009, "The net benefits to leverage," The Journal of Finance forthcoming.

Randall S. Kroszner and Philip E. Strahan , 2001, "Bankers on boards: monitoring, conflicts of interest, and lender liability", Journal of Financial Economics, Volume 62, Issue 3, December 2001, Pages 415-452.

LoPucki, Lynn, and Joseph Doherty, 2006, "Delaware bankruptcy: Failure in the ascendancy," University of Chicago Law Review 1387.

Linos, Katerina, 2006, Social Learning and the Development of Corporate Law (Harvard Law School student paper, Apr. 24, 2006)

Macey, Jonathan, 1991, “An Economic Analysis of the Various Rationales for Making Shareholders the Exclusive Beneficiaries of Corporate Fiduciary Duties", Stetson Law Review.

Manasco Dionne, Anna, 2007, "Living on the Edge: Fiduciary Duties, Business Judgment and Expensive Uncertainty in the Zone of Insolvency“, Stanford Journal of Law, Business \& Finance. Fall 2007. 13(1), pp 188.

Moodie, Gordon, 2004, "Forty Years of Charter Competition: A Race to Protect Directors From Liability?", Discussion Paper No. 1, Olin Center, Harvard University.

Murphy, Kevin J., 1999, "Executive Compensation", in Handbook of Labor Economics 3B, eds. Orley Ahenfelter and David Card, North-Holland.

Myers, Stewart, 1977, “Determinants of Corporate Borrowing”, Journal of Financial Economic, 5, 147175.

Myers, Stewart, 2003, "Financing of Corporations", in Handbook of the Economics of Finance, eds. George M. Constantinides, Milton Harris and René Stultz, Elsevier. 
Park, James, 2011, "Equity issuance and returns to distressed firms," working paper, University of British Columbia.

Rajan, Raghuram, and Andrew Winton, 1995, "Covenants and Collateral as Incentives to Monitor", Journal of Finance, Vol. 50, No. 4, pp. 1113-1146.

Rasmussen, Robert, and Randall Thomas, 2000, "Timing matters: Promoting forum shopping by insolvent corporations," Northwestern Law Review 94.

Rauh, Joshua, 2009, Risk Shifting versus Risk Management: Investment Policy in Corporate Pension Plans", Review of Financial Studies, 22(7), 2009, 2687-2734.

Shleifer, Andrei and Larry Summers, 1988, "Breach of trust in hostile takeovers" in Alan J. Auerbach, Corporate takeovers: Causes and consequences, University of Chicago Press.

Simpson Thacher, 2008, Client Memorandum, December 3.

Smith, Cliff W., and Jerold B. Warner, 1979, "Bankruptcy, secured debt, and optimal capital structure: Comment", Journal of Finance, 34(1).

Strömberg, Per, 2000, "Conflicts of interest and market illiquidity in bankruptcy auctions," Journal of Finance 40(6), 2641-2692.

Tirole, Jean, 2001, “Corporate Governance”, Econometrica, Vol. 69, No. 1 (Jan., 2001), pp. 1-35.

Vassalou, Maria and Yuhang Xing, 2004, “Default Risk in Equity Returns", Journal of Finance, 59(2), 831868.

Warga, Arthur, and Ivo Welch, 1993, "Bondholder losses in leveraged buyouts," Review of Financial Studies 6(4), 949-982.

Weiss, L, 1990, "Bankruptcy resolution: Direct costs and violation of priority of claims", Journal of Financial Economics, 27.

Welch, Ivo, 2004, "Capital Structure and Stock Returns", Journal of Political Economy, 112(1) 106-131. 
Zingales, Luigi, 1998, "Survival of the Fittest or the Fattest? Exit and Financing in the Trucking Industry", The Journal of Finance, Vol. 53, No. 3 (June), pp. 905-938.

Zingales, Luigi, 1998, "Corporate Governance." In: The New Palgrave Dictionary of Economics and the Law, MacMillan, London.

Zingales, Luigi, 2000, “In Search of New Foundations", Journal of Finance, 55: 1623- 1653.

\section{J. Legal cases (by date)}

Credit Lyonnais v Pathe Communications Delaware Civ A 12150. (Del. 1991)

re Buckhead America D (Del 1994)

Equity-Linked Investors, L.P., v Adams, (Del Ch 1997)

Official Committee of Unsecured Creditors of PHD, Inc. v. Bank One, (NA, 2003)

Production Resources Group, L.L.C. v. NCT Group, Inc., 863 A.2d 772, 790 (Del. Ch. 2004)

N. Am. Cath. Ed. Programming Found., Inc. v. Gheewalla, 930 A.2d 92, 101-03 (Del. 2007) 


\section{Figure 1 - Timeline of selected press and newswire coverage of the Credit Lyonnais case}

\section{November 1991-January 1992}

[Figure 1]

The star indicates 12/30/1991 (the date of Credit Lyonnais v Pathe Communications final ruling). Newswire coverage counts included Dow Jones Newswire, Associated press, PR Newswire, Reuters, and Agence France Presse. 


\section{Figure 2 - Equity issues: difference-in-difference}

[FIGURE 2]

The graph presents difference-in-difference estimates (1989-1991 vs. 1992-94, Delaware incorporation vs. incorporation in a non-Delaware state) of net equity issues as a fraction of lagged book assets. Both the differences are positive and significant at the $1 \%$ level. The difference-in-difference is $1.26 \%$ of assets (the difference in the increase in equity issues between firms incorporated in Delaware and those incorporated elsewhere), significantly different from zero at the $1 \%$ level. 


\title{
Figure 3 - Five day announcement returns: Delaware vs. non- Delaware firms, by book leverage quintile
}

\author{
[FIGURE 3]
}

The graph presents equal weighted excess return difference across Delaware and non-Delaware firms for Dec, 30, 1991 to January, 6, 1992 (the five trading days from the Credit Lyonnais v. Pathe Communications ruling), in basis points. The return differential is calculated separately for each quintile of 1991 book leverage. Leverage is defined as assets minus equity minus deferred taxes, over assets. Each data point is the difference between on average 308 Delaware and 343 non-Delaware firms. The 95\% confidence interval for the regression line is indicated with thin lines (standard deviations calculated from the 1/1/1991-12/27/1991 daily return differentials for the same groups of firms and allowing for serial correlation between daily returns). 
Figure 4 - Time patterns in the effect of Credit Lyonnais: Delaware - non Delaware difference in CapEx/Assets by year

[Figure 4]

The graph presents the average difference between Delaware and non-Delaware firms, after firm and year fixed effects and controls, by year, relative to 1987 . Vertical bars indicate $95 \%$ confidence interval. The dotted line indicates the period after Credit Lyonnais ruling. 


\section{Table 1: Summary statistics}

\begin{tabular}{|c|c|c|c|c|c|c|c|c|c|c|c|c|c|c|c|c|}
\hline & $\begin{array}{l}\text { Return } \\
\text { on } \\
\text { Assets }\end{array}$ & $\begin{array}{l}\text { Return } \\
\text { on } \\
\text { Sales }\end{array}$ & Assets & Sales & $\begin{array}{l}\text { Market } \\
\text { Value }\end{array}$ & $\begin{array}{l}\text { Dividend } \\
\text { s/ Assets }\end{array}$ & $\begin{array}{l}\text { Equity } \\
\text { issues/ } \\
\text { Assets }\end{array}$ & $\begin{array}{l}\text { Capex/ } \\
\text { Assets }\end{array}$ & $\begin{array}{c}\text { Capex } \\
\text { and R\&D } \\
\text { / Assets }\end{array}$ & $\begin{array}{l}\text { Capex } \\
\text { /Sales }\end{array}$ & $\begin{array}{l}\text { Std } \\
\text { dev. } \\
\text { ROA }\end{array}$ & $\begin{array}{c}\text { Equity } \\
\text { volatilit } \\
y\end{array}$ & $\begin{array}{c}\text { Asset } \\
\text { volati } \\
\text { lity }\end{array}$ & $\begin{array}{l}\text { Book } \\
\text { Levera } \\
\text { ge }\end{array}$ & $\begin{array}{c}\text { Net } \\
\text { leverag } \\
\mathrm{e}\end{array}$ & $\begin{array}{c}\text { Market } \\
\text { Leverag } \\
\text { e }\end{array}$ \\
\hline Mean & 0.083 & 0.100 & 1151.8 & 984.1 & 763.3 & 0.013 & 0.056 & 0.065 & 0.129 & 0.166 & 0.068 & 0.153 & 0.030 & 0.492 & 0.149 & 0.381 \\
\hline Median & 0.108 & 0.099 & 60.7 & 60.7 & 58.4 & 0.000 & 0.005 & 0.044 & 0.098 & 0.083 & 0.040 & 0.126 & 0.025 & 0.486 & 0.150 & 0.342 \\
\hline Standard dev & 0.147 & 0.222 & 7053.6 & 5154. & 3507.8 & 0.031 & 0.156 & 0.071 & 0.121 & 0.319 & 0.093 & 0.112 & 0.023 & 0.259 & 0.287 & 0.264 \\
\hline $\mathbf{N}$ & 29,688 & 28,599 & 31,609 & 31,52 & 32,925 & 28,291 & 26,105 & 30,681 & 16,557 & 15,959 & 13,722 & 23,531 & 29,75 & 30,883 & 29,993 & 30,313 \\
\hline \multicolumn{17}{|l|}{ 1989-1991: } \\
\hline Mean (Delaware) & 0.080 & 0.096 & 971.1 & 838.5 & 587.5 & 0.013 & 0.044 & 0.064 & 0.136 & 0.178 & 0.074 & 0.150 & 0.028 & 0.529 & 0.175 & 0.430 \\
\hline Mean (Other) & 0.084 & 0.093 & 757.2 & 664.0 & 502.2 & 0.013 & 0.040 & 0.063 & 0.116 & 0.134 & 0.071 & 0.146 & 0.027 & 0.499 & 0.176 & 0.422 \\
\hline $\begin{array}{l}\text { 1992-1994: } \\
\text { Mean (Delaware) }\end{array}$ & 0.084 & 0.095 & 1038.6 & 856.5 & 746.6 & 0.011 & 0.075 & 0.065 & 0.148 & 0.210 & 0.065 & 0.152 & 0.032 & 0.488 & 0.129 & 0.348 \\
\hline Mean (Other) & 0.090 & 0.103 & 851.3 & 701.8 & 603.0 & 0.014 & 0.058 & 0.062 & 0.116 & 0.130 & 0.062 & 0.163 & 0.033 & 0.461 & 0.130 & 0.341 \\
\hline
\end{tabular}

The sample is Compustat firms from 1989 to 1994. Return on assets is EBITDA over assets, return on Sales is EBITDA over Sales, Market Value is number of shares outstanding times end of year share price. Equity issues are calculated as in Baker, Stein and Wurgler (2003): the change in book equity minus the change in retained earnings, divided by assets, and is winsorized, The equity issuer dummy is equal to one if equity issues are at least $1 \%$ of assets. Standard deviation is the annualized standard deviation of eight quarterly roa changes (if less than one). Equity volatility is the annualized monthly standard deviation of returns over the last three years (if less than 1 ). Asset volatility is the Merton (1974) model implied annual asset volatility (if less than one). 


\section{Table 2. Investment - difference-in-difference results around Credit Lyonnais ruling}

\section{Dependent variable:}
Capex / Assets
(Capex + R\&D) / Assets
Capex / Sales

$+2$

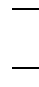

(1)

(2)

(3)

(4)

(5)

(6)

Sample:

\begin{tabular}{|c|c|c|c|c|c|}
\hline $\begin{array}{c}\text { Low distance to } \\
\text { default }\end{array}$ & $\begin{array}{c}\text { High distance } \\
\text { to default }\end{array}$ & $\begin{array}{c}\text { Low distance to } \\
\text { default }\end{array}$ & $\begin{array}{c}\text { High distance } \\
\text { to default }\end{array}$ & $\begin{array}{c}\text { Low distance } \\
\text { to default }\end{array}$ & $\begin{array}{c}\text { High distance } \\
\text { to default }\end{array}$ \\
\hline $0.0048 * * *$ & $0.0031^{*}$ & $0.0067 * *$ & 0.0027 & $0.0107 * * *$ & $0.0086 * *$ \\
\hline (0.0018) & $(0.0016)$ & $(0.0028)$ & (0.0025) & (0.0037) & $(0.0042)$ \\
\hline
\end{tabular}

Firm controls

Year Fixed Effects

Firm Fixed Effects

$x$
$x$
$X$

Adj R-squared

0.599

0.645

0.900

Observations

$N=9,638$

$N=8,971$

$N=4,993$

$N=4,978$

$N=5,001$

$N=4,982$

Number of clusters

252

284

208

236

208

236

Each column presents the coefficient estimates from an OLS regression. Firm controls are return on assets, return on sales, the log of assets (book value), the log of sales, the log of equity market value, depreciation over assets, leverage (defined as assets minus equity minus deferred taxes, over assets), and market (defined as assets minus book equity minus deferred taxes, over assets minus book equity plus market equity), two year stock return, and q (capped at 10). Low distance to default is any firm for which the 1989 log of the ratio of assets to debt was less than 4 times the standard deviation of assets, estimated following Merton (1974). Standard errors are clustered, where clusters are defined by the interaction of year and firm state of incorporation.

${ }^{*}$ significant at $10 \% ;{ }^{* *}$ significant at $5 \% ;{ }^{* *}$ significant at $1 \%$ 
Table 3. Equity Issues - difference-in-difference results around Credit Lyonnais ruling

Dependent variable:

\begin{tabular}{|c|c|c|c|c|}
\hline \multirow{2}{*}{ 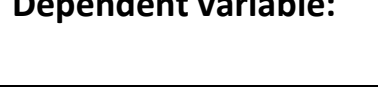 } & \\
\hline & (1) & (2) & (3) & (4) \\
\hline Sample: & $\begin{array}{c}\text { Low distance to } \\
\text { default }\end{array}$ & $\begin{array}{c}\text { High distance to } \\
\text { default }\end{array}$ & $\begin{array}{c}\text { Low distance to } \\
\text { default }\end{array}$ & $\begin{array}{l}\text { High distance to } \\
\text { default }\end{array}$ \\
\hline Delaware * Post 1991 & $\begin{array}{c}0.0089 * * \\
(0.0038)\end{array}$ & $\begin{array}{c}0.0018 \\
(0.0054)\end{array}$ & $\begin{array}{l}0.0179 * \\
(0.0093)\end{array}$ & $\begin{array}{c}0.0014 \\
(0.0127)\end{array}$ \\
\hline Firm controls & $x$ & $\mathrm{x}$ & $x$ & $x$ \\
\hline Year Fixed Effects & $x$ & $x$ & $x$ & $x$ \\
\hline Firm Fixed Effects & $x$ & $\mathrm{x}$ & $x$ & $x$ \\
\hline Adj R-squared & 0.311 & 0.409 & 0.264 & 0.328 \\
\hline Observations & $N=9,894$ & $N=8,967$ & $N=9,894$ & $N=8,967$ \\
\hline Number of clusters & 252 & 284 & 252 & 284 \\
\hline \multicolumn{5}{|c|}{$\begin{array}{l}\text { Each column presents the coefficient estimates from an OLS regression. Firm controls are return on assets, return on sales, the log of assets } \\
\text { (book value), the log of sales, the log of equity market value, depreciation over assets, leverage (defined as assets minus equity minus } \\
\text { deferred taxes, over assets), and market (defined as assets minus book equity minus deferred taxes, over assets minus book equity plus } \\
\text { market equity), two year stock return, and q (capped at 10). Low distance to default is any firm for which the } 1989 \text { log of the ratio of assets } \\
\text { to debt was less than } 4 \text { times the standard deviation of assets, estimated following Merton (1974). Standard errors are clustered, where } \\
\text { clusters are defined by the interaction of year and firm state of incorporation. }\end{array}$} \\
\hline
\end{tabular}

(1) (2) (3) (4)

Equity issues/ Assets $\quad$ Equity issues $>10 \%$ Assets 
Table 4. Payout - difference-in-difference results around Credit Lyonnais ruling

Dependent variable:

Dividends/ Assets Repurchases / Assets

\begin{tabular}{cccc}
\hline (1) & $(2)$ & $(4)$ & $(5)$ \\
\hline $\begin{array}{c}\text { Low distance to } \\
\text { default }\end{array}$ & $\begin{array}{c}\text { High distance } \\
\text { to default }\end{array}$ & $\begin{array}{c}\text { Low distance to } \\
\text { default }\end{array}$ & $\begin{array}{c}\text { High distance to } \\
\text { default }\end{array}$ \\
\hline-0.0003 & 0.0002 & -0.0004 & 0.0007 \\
$(0.0018)$ & $(0.0003)$ & $(0.0003)$ & $(0.0006)$ \\
$X$ & $X$ & $X$ & $X$ \\
$X$ & $X$ & $X$ & $X$ \\
$X$ & $X$ & $X$ & 0.314 \\
0.676 & 0.887 & 0.134 & $N=8,832$ \\
$N=10,051$ & $N=9,121$ & $N=9,664$ & 284 \\
244 & & & 251 \\
\hline
\end{tabular}

Number of clusters Each column presents the coefficient estimates from an OLS regression. Firm controls are return on assets, return on sales, the log of
assets (book value), the log of sales, the log of equity market value, depreciation over assets, leverage (defined as assets minus equity minus deferred taxes, over assets), and market (defined as assets minus book equity minus deferred taxes, over assets minus book equity plus market equity), two year stock return, and q (capped at 10). Low distance to default is any firm for which the 1989 log of the ratio of assets to debt was less than 4 times the standard deviation of assets, estimated following Merton (1974). Standard errors are clustered, where clusters are defined by the interaction of year and firm state of incorporation. * significant at $10 \%$; $* *$ significant at $5 \% ; * *$ significant at $1 \%$ 
Table 5. Volatility and risk - difference-in-difference results around Credit Lyonnais ruling

Dependent variable:

\section{Sample: \\ Delaware * Post 1991}

\begin{tabular}{ccccc}
\hline $\begin{array}{c}\text { Volatility of } \\
\text { ROA }\end{array}$ & $\begin{array}{c}\text { Volatility of } \\
\text { ROA }\end{array}$ & $\begin{array}{c}\text { Volatility of } \\
\text { ROA }\end{array}$ & $\begin{array}{c}\text { Asset } \\
\text { volatility }\end{array}$ & Equity volatility \\
\hline$(1)$ & $(2)$ & $(4)$ & $(5)$ & $(6)$ \\
\hline
\end{tabular}

\begin{tabular}{ccccc}
\hline $\begin{array}{c}\text { Low distance } \\
\text { to default }\end{array}$ & $\begin{array}{c}\text { High distance } \\
\text { to default }\end{array}$ & All firms & All firms & All firms \\
\hline & & & & \\
$-0.0076^{* *}$ & $0.0066^{* *}$ & -0.0006 & $-0.0071^{* * *}$ & $-0.0020^{* * *}$ \\
$(0.0036)$ & $(0.0026)$ & $(0.0023)$ & $(0.0019)$ & $(0.0004)$
\end{tabular}

\section{Firm controls \\ Year Fixed Effects \\ Firm Fixed Effects}

\section{Adj. R-squared}

\section{Observations}

$X$
$X$
$x$

0.710

$N=2,145$

76

$X$
$x$
$X$

0.797

$N=2,060$

$x$

$x$

$$
\mathrm{X}
$$

0.745

0.787

86

91

\section{Number of clusters}

Each column presents the coefficient estimates from an OLS regression. Firm controls are return on assets, return on sales, the log of assets (book value), the log of sales, the log of equity market value, depreciation over assets, leverage (defined as assets minus equity minus deferred taxes, over assets), and market (defined as assets minus book equity minus deferred taxes, over assets minus book equity plus market equity), two year stock price change, and q (capped at 10). Low distance to default is any firm-year for which the log of the 1989 ratio of assets to debt is less than 4 times the standard deviation of assets, estimated following Merton (1974). Standard errors are clustered, where clusters are defined by the interaction of year and firm state of incorporation.

* significant at $10 \% ;{ }^{* *}$ significant at $5 \% ; * * *$ significant at $1 \%$ 
Table 6: Leverage - difference-in-difference results around Credit Lyonnais ruling

Dependent variable:

Sample:
Delaware * Post 1991

\section{Firm controls}

Year Fixed Effects

Firm Fixed Effects

Adj. R-squared

\begin{tabular}{ccc}
\hline $\begin{array}{c}\text { Net Debt / Assets, } \\
\text { book }\end{array}$ & Debt / Assets, market & Interest Expense / Debt \\
\hline$(1)$ & $(2)$ & $(3)$ \\
\hline \multicolumn{1}{|c}{ All firms } & Allms & All firms \\
\hline $0.0066^{* * *}$ & $0.0036^{* *}$ & 0.0011 \\
$(0.0029)$ & $(0.0012)$ & $(0.0012)$ \\
& & \\
$X$ & $X$ & $X$ \\
$X$ & $X$ & $X$ \\
$X$ & $X$ & 0.450 \\
0.845 & 0.968 & $N=15,015$ \\
$N=18,604$ & $N=19,459$ & 284 \\
292 & 293 & $X$
\end{tabular}

\section{Number of clusters}

292

293

284

Each column presents the coefficient estimates from an OLS regression. Net debt / Assets. book is book debt minus cash, divided by book assets. Debt / Assets, market, is book debt divided by book debt plus market value of equity. Interest cost is net interest expense divided by book debt. Firm controls are return on assets, return on sales, the log of assets (book value), the log of sales, the log of equity market value, depreciation over assets, two year stock price change, and q (capped at 10) as well as lagged leverage. Leverage is either net debt over assets (defined as assets minus equity minus deferred taxes minus cash, over assets minus cash) or market debt over assets (defined as assets minus book equity minus deferred taxes, over assets minus book equity plus market equity). Specification (3) includes current book leverage and current market leverage rather than lagged leverage as independent variables. Standard errors are clustered, where clusters are defined by the interaction of year and firm state of incorporation.

\footnotetext{
${ }^{*}$ significant at $10 \% ;{ }^{* *}$ significant at $5 \% ; * * *$ significant at $1 \%$
} 
Table 7. Bond covenants after Credit Lyonnais - difference-in-difference results around Credit Lyonnais ruling

\begin{tabular}{|c|c|c|c|c|}
\hline \multirow[t]{2}{*}{ Dependent variable: } & $\begin{array}{c}\text { Bond has } \\
\text { covenants }\end{array}$ & $\begin{array}{c}\text { Number of } \\
\text { covenants, log }\end{array}$ & $\begin{array}{c}\text { Number of } \\
\text { covenants, log }\end{array}$ & $\begin{array}{c}\text { Number of } \\
\text { covenants, log }\end{array}$ \\
\hline & (1) & (2) & (3) & (4) \\
\hline Dependent variable mean & 0.835 & 1.481 & 1.778 & 1.783 \\
\hline Dependent variable st. dev. & 0.371 & 0.784 & 0.627 & 0.396 \\
\hline Sample: & All firms & All firms & Low DtD & High DtD \\
\hline Delaware * Post 1991 & $\begin{array}{c}-0.108 * * \\
(0.0527)\end{array}$ & $\begin{array}{l}-0.154 * \\
(0.085)\end{array}$ & $\begin{array}{c}-0.435^{* *} \\
(0.207)\end{array}$ & $\begin{array}{l}-0.058 \\
(0.058)\end{array}$ \\
\hline Bond time to maturity & $\begin{array}{l}-0.0010 \\
(0.0008)\end{array}$ & $\begin{array}{c}-0.0029 * * \\
(0.0013)\end{array}$ & $\begin{array}{c}0.002 \\
(0.003)\end{array}$ & $\begin{array}{l}-0.001 \\
(0.001)\end{array}$ \\
\hline Bond issue amount, log & $\begin{array}{c}0.0251^{* * *} \\
(0.0062)\end{array}$ & $\begin{array}{c}0.0435^{* * *} \\
(0.0090)\end{array}$ & $\begin{array}{c}0.100 * * \\
(0.046)\end{array}$ & $\begin{array}{c}0.098 \\
(0.079)\end{array}$ \\
\hline Seniority type Fixed Effects & $x$ & $x$ & $x$ & $x$ \\
\hline Coupon type Fixed Effects & $x$ & $x$ & $x$ & $x$ \\
\hline Year Fixed Effects & $x$ & $x$ & $x$ & $x$ \\
\hline Issuer Fixed Effects & $X(1,427)$ & $X(1,427)$ & $X(122)$ & $x(103)$ \\
\hline R-squared & 0.6739 & 0.737 & 0.735 & 0.815 \\
\hline Observations & $N=4,173$ & $N=4,173$ & $N=292$ & $N=295$ \\
\hline Number of clusters & 142 & 142 & 54 & 41 \\
\hline
\end{tabular}

Each column presents the coefficient estimates from an OLS regression. Each observation represents a corporate bond issued between 1990 and 1993. Bond has covenants is a dummy variable equal to one for bonds where the prospectus filed with the SEC indicates at least one covenant. The log of the number of covenants is the log of one plus the count of covenants in the prospectus (running from zero to 18). Seniority type is one of Junior Subordinate, Senior Secured, Senior Subordinate, Senior Unsecured, Subordinate and Not Ranked, as classified by Mergent. Coupon type is Fixed, Step-Up, Variable or Zero. Bond time to maturity is the number of years between issuance and maturity. Bond issue amount is the log of the face value at issue. Standard errors are clustered, where clusters are defined by year and issuing firm state of incorporation. Low distance to default (DtD) is below 6.25 . $^{*}$ significant at $10 \%$; ** significant at $5 \%$; ${ }^{* *}$ significant at $1 \%$ 


\section{Table 8. Announcement returns: Delaware - non Delaware differentials}

\begin{tabular}{|c|c|c|c|c|c|c|c|c|}
\hline & \multicolumn{2}{|c|}{ Raw return } & \multicolumn{2}{|c|}{ CAPM residuals } & \multicolumn{2}{|c|}{$\begin{array}{l}\text { Fama French three } \\
\text { factor residuals }\end{array}$} & \multicolumn{2}{|c|}{$\begin{array}{l}\text { Raw returns, alternative } \\
\text { standard errors }\end{array}$} \\
\hline & EW & VW & EW & VW & EW & VW & EW & VW \\
\hline & (1) & (2) & (3) & (4) & (5) & (6) & (7) & (8) \\
\hline One day return & $\begin{array}{c}60.6 * * * \\
(19.6)\end{array}$ & $\begin{array}{c}41.4^{* * *} \\
(6.8)\end{array}$ & $\begin{array}{c}40.9 * * \\
(19.6)\end{array}$ & $\begin{array}{c}24.0 * * * \\
(6.8)\end{array}$ & $\begin{array}{l}35.8^{*} \\
(19.6)\end{array}$ & $\begin{array}{l}25.8^{* * *} \\
(6.8)\end{array}$ & - & - \\
\hline Five day return & $\begin{array}{c}206 * * * \\
(41.9)\end{array}$ & $\begin{array}{l}55^{* * *} \\
(16.2)\end{array}$ & $\begin{array}{c}174 * * * \\
(41.1)\end{array}$ & $\begin{array}{l}27.5 * \\
(15.5)\end{array}$ & $\begin{array}{c}145 * * * \\
(41.4)\end{array}$ & $\begin{array}{c}38.4^{* *} \\
(15.2)\end{array}$ & $\begin{array}{c}206 * * * \\
(76.3)\end{array}$ & $\begin{array}{l}55 * * * \\
(18.3)\end{array}$ \\
\hline
\end{tabular}




\section{$\underline{\text { Table 9. Robustness tests }}$}

\section{Panel A: Alternative measures of financial distress}

\begin{tabular}{|c|c|c|c|c|c|c|}
\hline \multirow{3}{*}{$\begin{array}{l}\text { Grouping variable [ } 1989 \text { value } \\
\text { for distressed firms] }\end{array}$} & \multicolumn{2}{|c|}{$\begin{array}{c}\text { (Capex + R\&D)/ Assets } \\
\text { (Table 2) }\end{array}$} & \multicolumn{2}{|c|}{ Equity Issues (Table 3) } & \multicolumn{2}{|c|}{ ROA volatility (Table 4) } \\
\hline & (1) & $(2)$ & (3) & (4) & (5) & (6) \\
\hline & $\begin{array}{l}\text { Close to } \\
\text { distress }\end{array}$ & $\begin{array}{l}\text { Far from } \\
\text { distress }\end{array}$ & $\begin{array}{l}\text { Close to } \\
\text { distress }\end{array}$ & $\begin{array}{l}\text { Far from } \\
\text { distress }\end{array}$ & $\begin{array}{l}\text { Close to } \\
\text { distress }\end{array}$ & $\begin{array}{l}\text { Far from } \\
\text { distress }\end{array}$ \\
\hline Distance to default [4 or less] & $0.0048^{* * *}$ & $0.0031^{*}$ & $0.0089 * *$ & 0.0018 & $-0.0076^{* *}$ & $0.0026^{*}$ \\
\hline Net book leverage $[\mathrm{D} / \mathrm{V}>0.2]$ & $0.0058^{* * *}$ & 0.0039 & $0.0088^{* *}$ & 0.0036 & $-0.0057^{* * *}$ & 0.0008 \\
\hline Altman's z-score $[z<2.4]$ & $0.0165^{* * *}$ & 0.0004 & 0.0041 & $0.0058^{*}$ & -0.0009 & -0.0003 \\
\hline Non-dividend payer & $0.0072 * * *$ & 0.0019 & $0.0066^{*}$ & $0.0045^{*}$ & -0.0028 & -0.0002 \\
\hline
\end{tabular}

Each cell represents one regression. The column headings indicate dependent variables and the Table in which the baseline result for that variable can be found. The Rows indicate the variable along which the sample is split, and the numerical value at which the cutoff is done. All sort are based on 1989 values. Regressions include the same control variables ad the corresponding tables. For each regression, only one coefficient is reported: the estimated coefficient for the Delaware* Post 1991 interaction dummy.

${ }^{*}$ significant at $10 \% ;{ }^{* *}$ significant at $5 \% ;{ }^{* * *}$ significant at $1 \%$ 


\section{Panel B: Cross-sectional regressions}

\begin{tabular}{|c|c|c|c|c|c|}
\hline \multirow[t]{2}{*}{ Dependent variable: } & $\begin{array}{c}\text { Change in } \\
\text { (Capex + R\&D) / } \\
\text { Assets }\end{array}$ & $\begin{array}{c}\text { Change in } \\
\text { (Capex + R\&D) / } \\
\text { Assets }\end{array}$ & $\begin{array}{c}\text { Change in } \\
\text { Equity issues/ } \\
\text { Assets }\end{array}$ & $\begin{array}{c}\text { Change in } \\
\text { Equity issues/ } \\
\text { Assets }\end{array}$ & $\begin{array}{l}\text { Change in Net } \\
\text { Debt / Assets, } \\
\text { book }\end{array}$ \\
\hline & (1) & (2) & (3) & (4) & (7) \\
\hline Sample: & Low DDF & High DDF & Low DDF & High DDF & All firms \\
\hline Delaware & $\begin{array}{l}0.0065^{*} \\
(0.0037)\end{array}$ & $\begin{array}{c}0.0010 \\
(0.0028)\end{array}$ & $\begin{array}{c}0.0075^{* * *} \\
(0.0024)\end{array}$ & $\begin{array}{c}0.0030 \\
(0.0038)\end{array}$ & $\begin{array}{c}0.0162 * * * \\
(0.0042)\end{array}$ \\
\hline Firm controls & $x$ & $x$ & $x$ & $\mathrm{x}$ & $x$ \\
\hline Adj. R-squared & 0.074 & 0.144 & 0.178 & 0.097 & 0.193 \\
\hline Observations & $N=909$ & $N=767$ & $N=1,747$ & $N=1,329$ & $N=3,095$ \\
\hline Number of clusters & 35 & 39 & 42 & 46 & 48 \\
\hline \multicolumn{6}{|c|}{$\begin{array}{l}\text { Each column presents the coefficient estimates from an OLS regression. Dependent variables are change in Capex plus R\&D over assets, change in equity } \\
\text { issues over assets, change in volatility of ROA, and change in Net debt over book assets. Changes are calculated as the differences of the average value } \\
\text { during } 1991-1993 \text { and the average value 1988-1990. Firm controls are the change in return of assets, the change in return on sales, the change in log of } \\
\text { assets (book value), the change in log of sales, the change in log of equity market value, the change in depreciation over assets, change in book leverage } \\
\text { (defined as assets minus equity minus deferred taxes, over assets), and change in market leverage (defined as assets minus book equity minus deferred } \\
\text { taxes, over assets minus book equity plus market equity), change in two year stock returns, and change in q (capped at 10). In addition, the average log of } \\
\text { assets in 1988-1991, the average q in 1988-1991 and the average book leverage } 1988-1991 \text { are included as controls. The change in log of assets and the } \\
\text { change in depreciation over assets are excluded when Capex and R\&D over assets is the dependent variable, and change in book and market leverage are } \\
\text { excluded when equity issues and net debt over assets are the dependent variables. Low distance to default is any firm-year for which the log of the } 1989 \\
\text { ratio of assets to debt is less than } 4 \text { times the standard deviation of assets, estimated following Merton (1974). Standard errors are clustered by firm state } \\
\text { of incorporation. } \\
\text { * significant at } 10 \% ;{ }^{* *} \text { significant at } 5 \% ; * * * \text { significant at } \\
1 \%\end{array}$} \\
\hline
\end{tabular}




\section{Panel C: Regressions by quartile of distance to default}

Dependent variable:

(2)

Sample:

Quartile 1 DDF

(lowest)

Quartile 2 DDF

Quartile 3 DDF

Quartile 4 DDF

(highest)

\section{Firm controls}

Year Fixed Effects

\section{Firm Fixed Effects}

\begin{tabular}{ccc}
\hline (Capex + R\&D) / Assets & Equity issues/ Assets & Volatility of ROA \\
\hline$(1)$ & $(2)$ & $(3)$ \\
\hline All firms & & All firms \\
\hline $0.0131^{* * *}$ & All firms & $-0.0119^{*}$ \\
$(0.0050)$ & $0.0119^{*}$ & $(0.0068)$ \\
& $(0.0064)$ & \\
0.0025 & & $-0.0073^{* * *}$ \\
$(0.0030)$ & 0.0062 & $(0.0027)$ \\
& $(0.0043)$ & \\
0.0011 & & $0.0131^{* * *}$ \\
$(0.0034)$ & 0.0009 & $(0.0046)$ \\
& $(0.0058)$ & -0.0018 \\
0.0027 & & $(0.0016)$ \\
$(0.0030)$ & 0.0011 &
\end{tabular}

Each column presents the coefficient estimates from OLS regressions. Firm controls are return on assets, return on sales, the log of assets (book value), the log of sales, the log of equity market value, depreciation over assets, leverage (defined as assets minus equity minus deferred taxes, over assets), and market (defined as assets minus book equity minus deferred taxes, over assets minus book equity plus market equity), two year stock price change, and q (capped at 10). Distance to default is estimated following Merton (1974) and split into quartiles. The cutoffs are 2.02, 3.78 and 6.07. Standard errors are clustered, where clusters are defined by the interaction of year and firm state of incorporation.

${ }^{*}$ significant at $10 \% ; *$ significant at $5 \% ; * *$ significant at $1 \%$ 


\section{Panel D: Geographic and industry controls}

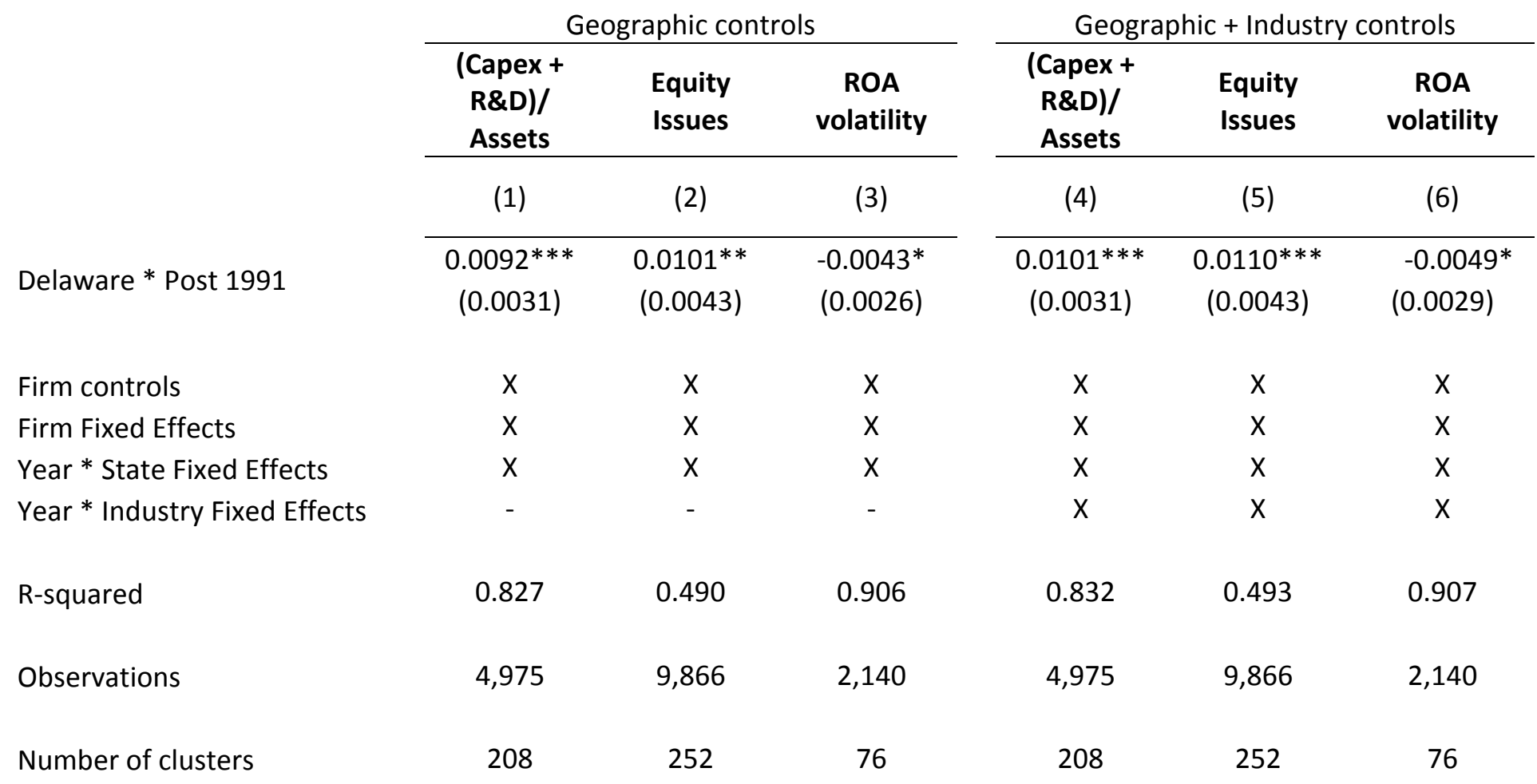

The table presents robustness tests of regressions in Tables 2, 3 and 4, with additional controls or shorter windows around 1991. Firms are included in the regression sample if the log of the 1989 (columns 1-3), 1988 (columns 4-5) or 1987 (columns 7-9) ratio of assets to debt is less than 4 times the standard deviation of assets, following Merton (1974). Each column represents one regression, corresponding to the regression $\mathrm{s}$ in the Tables above, but with some variation. In the first three columns, fixed effects are included for each year interacted with the HQ state of each firm. In columns four to six, further fixed effects for each Fama-French 12 industry interacted with year. Standard errors are clustered by the interaction of a firm's state of incorporation and the year.

* significant at $10 \% ;{ }^{* *}$ significant at $5 \% ; * *$ significant at $1 \%$ 


\begin{tabular}{|c|c|c|c|c|c|c|}
\hline & \multicolumn{3}{|c|}{ Four year window } & \multicolumn{3}{|c|}{ Five year window } \\
\hline & $\begin{array}{c}\text { (Capex + } \\
\text { R\&D)/ } \\
\text { Assets }\end{array}$ & $\begin{array}{l}\text { Equity } \\
\text { Issues }\end{array}$ & $\begin{array}{c}\text { ROA } \\
\text { volatility }\end{array}$ & $\begin{array}{c}\text { (Capex + } \\
\text { R\&D)/ } \\
\text { Assets }\end{array}$ & $\begin{array}{l}\text { Equity } \\
\text { Issues }\end{array}$ & $\begin{array}{c}\text { ROA } \\
\text { volatility }\end{array}$ \\
\hline & (1) & (2) & (3) & (4) & (5) & (6) \\
\hline Delaware * Post 1991 & $\begin{array}{c}0.0060 * * * \\
(0.0023)\end{array}$ & $\begin{array}{c}0.0053 \\
(0.0037)\end{array}$ & $\begin{array}{c}-0.0086^{*} \\
(0.0049)\end{array}$ & $\begin{array}{r}0.0053^{* *} \\
(0.0023)\end{array}$ & $\begin{array}{l}0.0058 * \\
(0.0034)\end{array}$ & $\begin{array}{l}-0.0088 \\
(0.0056)\end{array}$ \\
\hline Firm controls & $\mathrm{x}$ & $x$ & $\mathrm{x}$ & $\mathrm{x}$ & $\mathrm{x}$ & $x$ \\
\hline Year Fixed Effects & $x$ & $x$ & $x$ & $x$ & $x$ & $x$ \\
\hline Firm Fixed Effects & $\mathrm{x}$ & $x$ & $\mathrm{x}$ & $x$ & $\mathrm{x}$ & $x$ \\
\hline R-squared & 0.782 & 0.420 & 0.835 & 0.749 & 0.387 & 0.738 \\
\hline Observations & 6,536 & 12,829 & 2,074 & 15,086 & 15,421 & 2,040 \\
\hline Number of clusters & 277 & 331 & 76 & 409 & 407 & 75 \\
\hline
\end{tabular}

The table presents robustness tests of regressions in Tables 2, 3 and 4, with additional controls or shorter windows around 1991. Firms are included in the regression sample if the log of the 1989 (columns 1-3), 1988 (columns 4-5) or 1987 (columns 7-9) ratio of assets to debt is less than 4 times the standard deviation of assets, following Merton (1974). Each column represents one regression, corresponding to the regression $s$ in the Tables above, but with some variation. In the first three columns, the event window is $[1988,1991]$ before and $[1992,1995]$ after, and in columns four to six, it's $[1987,1991]$ before and $[1992,1996]$ after. Standard errors are clustered by the interaction of a firm's state of incorporation and the year.

* significant at $10 \% ;{ }^{* *}$ significant at $5 \% ;{ }^{* * *}$ significant at $1 \%$ 
'See Fama and Miller (1972), Jensen and Meckling (1976), and Myers (1977).

ii See Myers (2003) for list of possible agency problems between equity and debt (which can generate costs of financial distress). Several are related to the option-like features of equity (Black and Scholes, 1973).

iii An efficient corporate governance system requires that management answers to one clear stakeholder group, and equity, being residual claimants, is the most vulnerable stakeholder. Other stakeholders, such as creditors, are assumed to be able to protect themselves by contractual and other means (e.g. covenants). See e.g. Tirole (2001) or Jensen (2001).

iv Many of these mechanisms rely on private contracting, and if contracting is frictionless, there is no room for fiduciary duties, or indeed any other forms of corporate governance, to matter. See Zingales (1998).

${ }^{v}$ See Johnson et al (2000) for a discussion of the business judgment rule. Under this rule, courts assume that managers acted in the corporate interest when assessing their decision-making ex post.

vi Such insurance provides incomplete coverage, for example through limits to coverage and does not shield managers from reputational costs.

vii However, a number of U.S. states have constituency statutes which allow corporate directors to take into account the interests of non-owners, e.g. workers, customers, creditors, and suppliers in certain situations (notably hostile takeovers). Except for two states (Indiana and Pennsylvania), these laws do not require directors to consider non-owner interests.

viii The case is Delaware Civil Action No. 12150, submitted Nov, 6, 1991 and decided Dec, 30, 1991. The ruling is available online at http://blogs.law.harvard.edu/corpgov/files/2007/06/20070606\%20Credit\%20Lyonnais.pdf. We refer to the case as Credit Lyonnais 1991 or Credit Lyonnais in the text. A list of the cases we refer to is included at the end of the paper.

${ }^{\text {ix }}$ This market estimate is not necessarily accurate, nor identical to the long term assessment. The event study methodology is not useful for estimating the latter, unfortunately, so we study only the short term market view. 
${ }^{x}$ See e.g. Almeida and Philippon (2007), Elkhami et al (2009), and Korteweg (2009) for recent studies reaching different conclusions about whether costs of financial distress are large enough to explain capital structure in publicly traded firms.

${ }^{x i}$ Among papers that find evidence pointing away from equity-debt conflicts are Parrino and Weisbach (1999) and Rauh (2009) (in both cases, the topic is risk shifting). Among papers with more supportive findings are Esty (1997) (for financial firms), Shleifer and Summers (1988) (arguing that equity appropriates value from other stakeholders), and Asquith, Gertner and Scharfstein (1994) (providing indirect evidence of conflicts among financially distressed junk bond issuers). So far, the strongest case for the existence of these agency costs is probably indirect, coming from the fact that debt contracts include a multitude of covenants aiming to curb opportunistic behavior of management (see Smith and Warner, 1979).

xii What was generally believed by practicing corporate lawyers and corporate directors is more important than whether or not the perception was correct, i.e. whether this belief was an accurate prediction of hypothetical future case outcomes. There is uncertainty about many legal rules under a commonlaw legal system (such as the in the US). See Gennaioli and Shleifer (2007) for a discussion of this.

xiii This followed extensive coverage of the case during the Fall by both domestic and international media (e.g., eight Reuters and twenty six total newswires about the case in December alone).

${ }^{\text {xiv }}$ The Credit Lyonnais case is cited 169 times according to Lexis-Nexis, whereas the Westlaw database reports 612 citations (both based on search in July 2009). Among these are 56 legal cases, many court documents, and a large number of legal articles.

${ }^{x v}$ John Coffee, American Bar Association annual meeting Aug. 7-10, 1993, cited in BNA Corporate Counsel Daily, Aug. 30, 1993.

xvi See, e.g., re Buckhead America D Del 1994 and Equity-Linked Investors, L.P., v Adams Del Ch 1997.

${ }^{\text {xvii }}$ An Ohio court described the rejection of Credit Lyonnais duties due to that state's constituency statutes in the following manner: "...because Ohio Revised Code Section 1701.59 provides that directors are permitted but not required to evaluate the interests of creditors, that there is no duty for directors to consider creditors when making decisions", Official Committee of Unsecured Creditors of PHD, Inc. v. Bank One, NA, 2003. 
xviii For example, the main coefficient estimate for investment (testing a prediction of debt overhang) in our full sample is 48 basis points for about 9,600 observations. Excluding non-constituency states, the same coefficient estimate becomes 62 basis points based on 8,300 observations. Notice that the prejudicial relevance of Credit Lyonnais in the remaining twenty states is very questionable. For simplicity, we stay with the full sample throughout the paper.

${ }^{x i x}$ This adjustment limits $Q$ to a maximum value of ten.

${ }^{x x}$ The goal of this is to avoid data errors. These limits correspond to a round number right above the $99^{\text {th }}$ percentile, and its reciprocal, except for leverage and depreciation over assets, where the lower bound we use is zero for conceptual reasons. If we winsorize instead of eliminating observations throughout, results are very similar. This is also true for dependent variables. If we cut-off exactly at the first and $99^{\text {th }}$ percentiles, we also get similar results.

${ }^{\mathrm{xxi}}$ We have used winsorizing instead of dropping observations, with similar results.

xxii For the 1991-1994 data, the following differences are significant at the 1\% level: investment and R\&D over assets, investment over sales, and (gross) book leverage. The difference in sales and assets is significant in logs (the table reports levels).

${ }^{x x i i i}$ The shorter time window we use in our main tests can be considered the more conservative approach, however. Longer time windows can give rise to biases in differences-in-differences estimates because of time trends (see Duflo et al (2004).

${ }^{\text {xxiv }}$ Consistent with this argument, Park (2011) finds that distressed equity-issuers underperform in their long-run stock returns.

${ }^{x x v}$ This specific cutoff is essentially arbitrary, reflecting the fact that being in the vicinity of financial distress or the perception of being there is not easily defined. However, the exact value of the cutoff does not affect our results. We sort on 1989 distance in order to keep the set of firms stable throughout the tests (except when we change sample period, in which case we always sort on the first year in the sample).

${ }^{x x v i}$ We cannot identify coefficients for state of incorporation dummies, given that we have firm fixed effects in all regressions. We report results for regressions including state and year interaction fixed effects (i.e. separate indicators for each year in each state) in Table 9.

xxvii Covenants are much less likely to matter for the investment results reported above. Covenants that limit investment in the upward direction are common, but we find an increase in investment, meaning that there was (more) underinvestment prior to Credit Lyonnais. A covenant that dealt with this 
would force a firm to undertake profitable investment. Covenants that force investment up or force equity issues (i.e. to avoid debt overhang) are probably difficult to write and enforce, and we are not aware of their use in debt contracts. There are covenants that (implicitly) require equity issuance, however, although these are not as common as the forms that limit investment or payout.

xxviii Some of these observations may also be associated with mergers in which the acquirer paid with stock.

${ }^{\text {xxix }}$ We have found the same absence of an effect using alternative normalizations of dividends and repurchases, including net income, cash flow and market value of equity.

${ }^{\mathrm{xxx}}$ We have included investment (capex over assets) as a further control, but it does not affect the coefficient of interest, so we present results with the same set of controls as in other regressions.

xxxi For example, the trade-off theory predicts that lower distress costs allow firms to take advantage of the tax shields provided by higher leverage.

xxxii Covenants are written at issuance (ex-ante), with a view to possible adverse future situations (ex-post), so even for Delaware firms doing well at the time of security issuance, the Credit Lyonnais changes may have mattered to the optimal set of covenants.

xxxiii This higher distance to default may also reflect the conditioning on finding a ticker-based link to Compustat data, which is presumably more likely for large, long-lived firms.

${ }^{\text {xxiv }}$ As mentioned above, Reuters, Dow Jones Newswire and PR Newswire reported on the ruling on Dec 30 and many newspapers covered the ruling in their print editions on Dec, 31, 1991 (including the Wall Street Journal, the Washington Post, the New York Times and the Financial Times). Of course, while media coverage facilitates awareness of the ruling, it does not necessarily imply that market prices will react or, if they react, that the reaction will be correct from the point of view of a future observer. Like all short-run event studies, we test what the market's views at the time were.

${ }^{x x x v}$ We have also looked at firms with large net equity issuance in 1992 as a way to identify firms where equity holders might have lost from Credit Lyonnais. This is consistent with our findings that distressed firms increased equity issuance after the ruling, and may be a more precise way of identifying the 
firms with big conflicts of interest between equity and debt. Of course, as with any measure of distress, this is just an estimate. Nevertheless, it turns out that for firms issuing more than $5 \%$ of assets in equity in 1992, the relative performance of Delaware firms on 12/30/1991 is negative (borderline significant).

${ }^{x x x v i}$ The variables give different results because they sort firms differently. All four distress variables are correlated, but the correlations are fairly low, ranging from 0.1 to 0.4 (omitting signs).

xxxvii In the baseline regressions, we deal with this through state-year clustering and firm fixed controls. This may well be sufficient, but using an alternative approach to deal with the problem can increase our confidence in the results.

xxxviii We replicated the methodology for used for Credit Lyonnais for the cases separately, and for them jointly (using 2002-2004 as the before and 2008-2010 as the after periods).

${ }^{\text {xxxix }}$ For example, indirect distress costs are an important part of how the trade-off theory of capital structure is usually understood (see Myers 2003).

${ }^{x l}$ If some of the gains are tax savings, the net welfare benefit is lower than what we estimate, since tax revenues can have welfare benefits. If market leverage increases by 0.25 and tax rates are 0.4 , the tax saving implied are about 10 basis points of firm value, or about 20 basis point of equity for a typical firm. This is modest compared to most of the valuation estimates provided in Table 7. 